\title{
Vibrational Studies of Different Human Body Disorders Using FTIR Spectroscopy
}

\author{
S. Kumar ${ }^{1}$, Reena ${ }^{2}$, S. Chaudhary ${ }^{1}$, Sweety ${ }^{1}$, Deep Chand Jain ${ }^{3}$ \\ ${ }^{1}$ Department of Physics, Medical Physics Research Laboratory, D.A.V. (P.G.) College, Muzaffar Nagar, India \\ ${ }^{2}$ Department of Mathematics, Shri K. K. Jain College, Khatauli, India \\ ${ }^{3}$ Department of Neurology, Safdarjang Hospital, New Delhi, India \\ Email: 'sanjeev1962@yahoo.co.in, sanjeev1962kumar@rediffmail.com, \\ reena math@rediffmail.com, drdcjain@gmail.com
}

Received 8 January 2014; revised 15 February 2014; accepted 22 February 2014

Copyright (C) 2014 by authors and Scientific Research Publishing Inc.

This work is licensed under the Creative Commons Attribution International License (CC BY).

http://creativecommons.org/licenses/by/4.0/

(c) (i) Open Access

\begin{abstract}
Some of the important features of the bands occur in the present study. The band called amide $A$ is available in all the diseased and healthy controls and the frequency of the band ranges from 3380 $\mathrm{cm}^{-1}$ to $3480.74 \mathrm{~cm}^{-1}$. The band due to $\mathrm{C}-\mathrm{H}$ band and called hydrocarbon band was found only in paralytic and Alzheimer diseased along with normal healthy controls. Carbide band $(C=C)$ is found only in Duchenne muscular dystrophy, paralytic and Alzheimer's disease patients. Amide I was intact in all disorders with normal persons. Peroxide band (0-0) was found in all the cases of study. Amide IV band was found in paralytic, muscular dystrophy, Alzheimer's diseases and normal controls. The amide $V$ band was found in Alzheimer's diseases only. The appearance or disappearance of the bands is a good sign to understand the mechanisms at the molecular level. FTIR spectroscopy may help in the diagnosis of the disease at the early stage of the onset. This spectroscopy can be used nicely for the study of hair, vaginal fluid, nails, urine, mucus, semen, synovial fluid, blood, hemoproteins, skin, and tears for human beings. We can also use it to understand the effect of adulteration on food and paint technology. FTIR is an indicator to explore the changes occurring at molecular level.
\end{abstract}

\section{Keywords}

Fourier Transform Infrared (FTIR); ImmunoglobuinG (IgG); Epilepsy (E); Migraine (M); Paralysis (P); Alzheimer's Diseases (AD); Duchenne Muscular Dystrophy (DMD)

\section{Introduction}

Our main attention is concentrated on Fourier Transform Infrared (FTIR) Spectroscopy. This spectroscopy is a "Corresponding author. 
tool used to detect common contaminants, molecular deformations and complexities in other biological fluids such as serum, plasma hemoglobin molecule, seminal fluid, vaginal fluid, synovial fluid, tears, saliva and Cerebro Spinal Fluid (CSF) and some other components such as nails, skin, and hair.

FTIR is based on the fundamental principle of molecular spectroscopy. This broad ranging area of physics and chemistry covers multitude experimental techniques.

We would like to give some facts regarding the principle of this technique. Specific molecules absorb light energy at specific wavelengths. These are called resonance frequencies. Water molecule $\left(\mathrm{H}_{2} \mathrm{O}\right)$ resonates around $3450 \mathrm{~cm}^{-1}$ (wave number in unit) in the infrared region of the electromagnetic spectrum.

FTIR spectrophotometer works by taking a very small quantity of the sample and introducing it to the infrared cell. A cell may be a pellet or liquid container. An infrared light source is fitted with this cell and illuminated by the source. A spectrograph is obtained and the range of the spectrum started from $4000 \mathrm{~cm}^{-1}$ to $400 \mathrm{~cm}^{-1}$. The intensity of light transmitted through the sample is measured at each wave number allowing the amount of light absorbed by the sample to be studied. We can determine the exact spectrum of the desired sample by difference of the spectrum before and after the illumination of the infrared source of light. This is known as the infrared spectrum of the sample.

The resonance frequencies of a molecule are due to the presence of molecular functional groups specific to the molecule. A functional group is simply a group of two or more atoms bonded together in a specific way. In the water molecule $\left(\mathrm{H}_{2} \mathrm{O}\right)$ the functional group is $\mathrm{O}-\mathrm{H}$. This group contributes to the resonance frequency around $3450 \mathrm{~cm}^{-1}$. It is quite possible to determine the presence of different molecules in the sample. It can be done by measuring the absorption at different wavelengths.

Whenever a resonance with one of the constituent molecules present in the sample is met, the amount of light absorbed increases or conversely the amount of light transmitted through the sample decreases. This is known as attenuation cell FTIR spectrophotometer.

FTIR is very useful for identifying chemicals that are either organic, inorganic or biological. It is used to quantitative some components of an unknown mixture. It can be applied to the analysis of solids, liquids and gases. The term FTIR refers to a fairly recent development in the manner in which the data is collected and converted from an interference pattern of a spectrum. This spectroscopy is the powerful tool for identifying types of chemical bonds (functional groups). The wavelength of light absorbed is characteristic of the chemical bond [1].

A molecule has a number of fundamental vibrational frequencies and that each may be associated with absorption of radiation of its own frequency. There are $3 \mathrm{~N}-6$ fundamental frequencies for a general molecule containing $\mathrm{N}$ atoms and for special molecules with degenerate frequencies, free internal rotations, etc. The frequency ranges from $100 \mathrm{~cm}^{-1}$ to $4000 \mathrm{~cm}^{-1}$. The absorption bands generally lie in the infrared region. Absorption may occur at nonfundamental frequencies if two or more fundamental modes of vibration are excited simultaneously. The corresponding absorption is generally weak.

The infrared absorption spectrum of a complex molecule may show a large number of absorption bands of different intensities and with an irregular frequency pattern. Since the whole spectrum is characteristic of the molecule and no two species of molecule have exactly the same absorption pattern. We can use the spectra to identify compounds [2].

The molecular vibrations associated with infrared absorption are strictly vibrations of the entire molecule. It happens that the distortion is largely confined to one section of the molecule. If this section recurs in different molecules, the associated infrared absorption will reappear at essentially the same frequency and approximately the same intensity. This happens so, reliably that the presence or absence of absorption at a particularly frequency can be used to infer the presence or absence of the chemical grouping concerned. The absence of groups is more reliably determined. Absorption in a certain region may arise from some unusual combination of groupings which would be separately transparent.

Such frequencies associated with chemical groupings are called characteristic group frequencies.

\section{Basic Theory of Infrared Vibrational Spectroscopy}

Theoretical details of infrared spectroscopy are given here. A vibrating diatomic molecule can be approximated to a linear harmonic oscillator, whose frequency of vibration can be calculated on the classical lines using New- 
ton's equation of motion [3]. A rigid diatomic molecule is shown in Figure 1.

If we suppose the bond distorted from its equilibrium length $r_{e}$ to a new length $r$. Restoring forces on each atom of a diatomic molecule can be calculated as.

$$
m_{1} \frac{\mathrm{d}^{2} r_{1}}{\mathrm{~d} t^{2}}=-k\left(r_{0}-r_{e}\right)
$$

We know that $F=-k(x)$ Hook's law. Or

$$
m_{2} \frac{\mathrm{d}^{2} r_{2}}{\mathrm{~d} t^{2}}=-k\left(r_{0}-r_{e}\right)
$$

Here $k$ is known as force constant and it is a measure of the stiffness of the bond.

$r_{1}$ and $r_{2}$ are the positions of atom 1 and 2 relative to the Centre of Mass (C. M.) of the molecule.

We have consider a diatomic molecule with an internuclear distance $r_{0}$. The molecule has a natural rotation about the axis through its centre of gravity $\mathrm{C}$. The moment of inertia of the molecule is given here.

$$
I=m_{1} r_{1}^{2}+m_{2} r_{2}^{2}
$$

Now we can write

and

$$
m_{1} r_{1}=m_{2} r_{2}
$$

$$
r_{0}=r_{1}+r_{2}
$$

using Equation (3) and Equation (4) we can calculate

$$
r_{1}=\left(\frac{m_{2}}{m_{1}+m_{2}}\right) r_{0}
$$

and

$$
r_{2}=\left(\frac{m_{1}}{m_{1}+m_{2}}\right) r_{0}
$$

Substituting the values of $r_{1}$ and $r_{2}$ in Equation (3)

$$
\begin{gathered}
I=\frac{m_{1} m_{2}^{2}}{\left(m_{1}+m_{2}\right)^{2}} r_{0}^{2}+\frac{m_{2} m_{1}^{2}}{\left(m_{1}+m_{2}\right)} r_{0}^{2}=\frac{m_{1} m_{2}}{\left(m_{1}+m_{2}\right)} r_{0}^{2}=\mu r_{0}^{2} \\
I=\mu_{0} r_{0}^{2}
\end{gathered}
$$

$\mu_{0}$ is reduced mass and defined as

$$
\mu_{0}=\frac{m_{1} m_{2}}{m_{1}+m_{2}}
$$

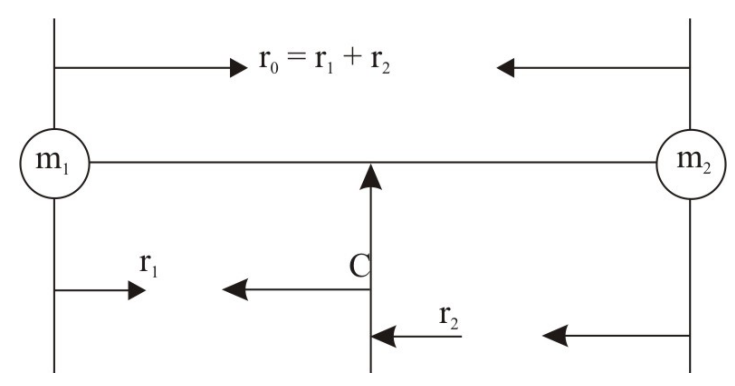

Figure 1. A rigid diatomic molecule treated as two masses $m_{1}$ and $m_{2}$ joined by a rigid base of length $r_{0}=$ $r_{1}+r_{2}$. 
Substituting the value of $r_{1}$ from Equation (6) in Equation (1), we get

$$
m_{1}\left(\frac{m_{2}}{m_{1}+m_{2}}\right) \frac{\mathrm{d}^{2} r_{0}}{\mathrm{~d} t^{2}}=-k\left(r_{0}-r_{e}\right)
$$

Since $r_{e}$ is constant its differentiation with respect to $t$ will be zero. We can write

$$
\frac{\mathrm{d}^{2} r_{0}}{\mathrm{~d} t^{2}}=\frac{\mathrm{d}^{2}\left(r_{0}-r_{e}\right)}{\mathrm{d} t^{2}}
$$

Substituting the value of $\frac{\mathrm{d}^{2} r_{0}}{\mathrm{~d} t^{2}}$ from Equation (12) in Equation (11) and we get

$$
\frac{\left(m_{1} m_{2}\right)}{\left(m_{1}+m_{2}\right)} \frac{\mathrm{d}^{2}}{\mathrm{~d} t^{2}}\left(r_{0}-r_{e}\right)=-k\left(r_{0}-r_{e}\right)
$$

If we put $r_{0}-r_{e}=x$ and

$$
\frac{m_{1} m_{2}}{m_{1}+m_{2}}=x_{0}
$$

using Equation (11).

Here $x$ represent the displacement of the bond length from its equilibrium position.

Now we can write Equation (11) as

$$
\mu_{0} \frac{\mathrm{d}^{2} x}{\mathrm{~d} t^{2}}=-k x
$$

or

$$
\frac{\mathrm{d}^{2} x}{\mathrm{~d} t^{2}}+\frac{k}{\mu_{0}} x=0
$$

or

$$
\frac{\mathrm{d}^{2} x}{\mathrm{~d} t^{2}}+\omega^{2} x=0
$$

Equation (14) is the Equation of Simple Harmonic Motion (S.H.M.) with frequency of vibration can be expressed in $\mathrm{cm}^{-1}$. It is called wave number.

Now

$$
\begin{gathered}
v=\frac{1}{c} \sqrt{\left(\frac{k}{m^{\prime}}\right)} \\
v=\frac{1}{c} \sqrt{\left(\frac{k}{m^{\prime}}\right)}=\frac{1}{2 \pi c} \sqrt{\left(\frac{k}{m^{\prime}}\right)} c^{-1}
\end{gathered}
$$

Vibrational energies, like other molecular energies are quantised. These are permitted energies for any particular system. It can be calculated from Schrödinger eqn. The eigen values for the energy of a linear harmonic oscillator are given here.

$$
E v=\left(v+\frac{1}{2}\right) h c \omega
$$

$v$ is known as vibrational quantum number.

The force constant can be calculated as

$$
K=4 \pi^{2} c^{2} \mu_{0} v^{2} N m^{-1}
$$

Stuart, B. [4] has studied biological applications of infrared spectroscopy and lot of calculations made regarding the specifications of a particular bond.

By measuring at specific frequency over time, changes in the character or quantity of a particular bond can be measured. Schmit, J. et al. [5] have applied this technique to microbiol and material analysis and given the information regarding the functional groups within the sample. It will absorb the infrared radiation and vibrate in 
one of a number of ways, either stretching, bending, deformation or combination vibrations.

The intensities of the bands in the spectrum are proportional to the concentration of their respective functional groups.

Lambert-Beer's law shows

$$
\begin{aligned}
& I=I_{0} \mathrm{e}^{\varepsilon b c} \\
& \frac{I}{I_{0}}=A=\varepsilon b c
\end{aligned}
$$

where, $I_{0}=$ Incident radiation; $I=$ Transmitted radiation,

$A$ is the absorption of the band; $b$ is the path length,

$\varepsilon$ is the molar proportionality constant called molar absorptivity. It is the characteristic of each functional group,

$C$ is the concentration of the functional group.

FTIR spectroscopy requires more sample preparation and does not have the ability of confocal imaging. The physical effect of infrared may be created by the procedure of absorption and influences the dipole and ionic bands such as $\mathrm{O}-\mathrm{H}, \mathrm{N}-\mathrm{H}$ and $\mathrm{C}=\mathrm{O}$. This spectroscopy is due to changes in dipole moment during molecular vibration.A block diagram of FTIR spectrophotometer is shown in Figure 2.

\section{Review of the Literature}

Naumann, D. [6] has studied some ultra structural information on intact, living bacterial cells and related cellwall fragments by using this technique.

One of the strategies employed by the emergent science of metabolism is metabolic fingerprinting. It involves

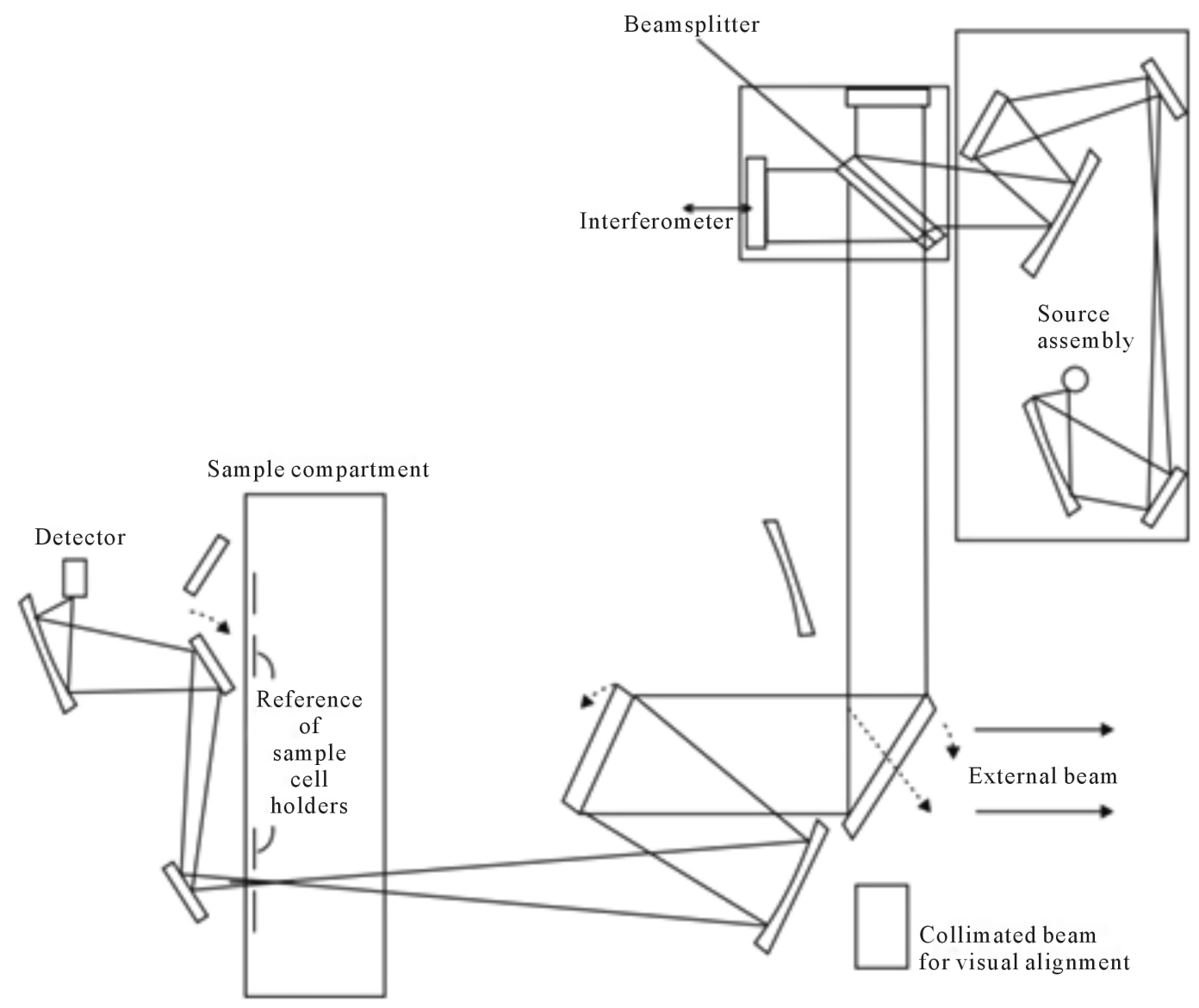

Figure 2. A block diagram of FTIR spectrophotometer. 
rapid, high-throughput global analysis to discriminate between the different biological blood samples of complex body disorders. It has been reported that whether clinical, biophysical or biochemical in nature, the clinical tests have been inconsistent and contradictory. Many clinicians thought these tests are unrealistic. Research continues for the optimum diagnostic test for the complex body disorders. FTIR was developed in order to overcome the limitations encountered with dispersive instruments. The main problem was very slow scanning process.

Naumann, D. et al. [7] have studied the rapid differentiation and identification of pathogenic bacteria using this spectroscopy and multivariate statistical analysis. They have given their views to develop a method. The method for measuring all of the infrared frequencies simultaneously was needed. The solution of this problem was developed. It is a well established and developing analytical method, which allows for rapid, high throughput, non-destructive analysis of a wide range of sample types.

Ellis, D. I. et al. [8] have studied metabolic profiling with the help of this spectroscopy and reported that the vibration in the wave number region $2800 \mathrm{~cm}^{-1}$ to $3050 \mathrm{~cm}^{-1}$ can be ascribed to $\mathrm{CH}_{2}$ and $\mathrm{CH}_{3}$ stretching vibrations from fatty acids. The vibrations in the region $1500 \mathrm{~cm}^{-1}$ to $1750 \mathrm{~cm}^{-1}$ are ascribed to $\mathrm{C}=\mathrm{O}, \mathrm{N}-\mathrm{H}$ and $\mathrm{C}-\mathrm{N}$ from proteins and peptides.

Krimm, S. et al. [9] have studied in detail the vibrational spectroscopy and provide a base for the conformation of peptides, polypeptides and proteins. Authors have given the ranges of amide bands for the conformation of the different types of proteins. They have shown that amide II band is a mixture of $\mathrm{N}-\mathrm{H}$ bending vibration (40\% - 60\%) and from the C-N stretching vibration (18\% - 40\%). This band is very sensitive. Amide III and IV bands are very complex in nature resulting from a mixture of so many coordinate displacements. It has been seen that out of plane motions are found in amid V, VI and VII bands.

Amide A band is due to N-H stretching vibration. This mode of vibration does not depend on the backbone conformation but is very sensitive to the strength of a hydrogen bond. It has wave numbers between $3225 \mathrm{~cm}^{-1}$ and $3280 \mathrm{~cm}^{-1}$ for hydrogen bond lengths between 2.69 to $2.85 \AA$.

Amide I band the most intense absorption band in proteins. It is governed by the stretching vibrations of the $\mathrm{C}=\mathrm{O}(70 \%-85 \%)$ and $\mathrm{C}-\mathrm{N}$ groups $(10 \%-20 \%)$. Its frequency is found in the range between $1600 \mathrm{~cm}^{-1}-1700$ $\mathrm{cm}^{-1}$. The exact band position is determined by the backbone conformation and the hydrogen bonding pattern.

Amide II band results from the N-H bending vibration ( $40 \%-60 \%)$ and from the C-N stretching vibration (18\% - 40\%). This band is conformationally sensitive. Amide III and amide IV are very complex bands resulting from a mixture of several coordinate displacements. The out of plane motions are found in amide V, VI and VI bands.

Movasoghi, et al. [10] have reviewed the literature and supplied the relevant informations regarding the peak position intensities and frequencies of the bands and provide a data base, which is useful in the field of research and industries globally.

Kong, J. et al. [11] have studied secondary structures of protein and given a detailed knowledge of spectroscopy of proteins. They have given their views as the quantitative estimation of protein secondary structures is based on the assumption that any protein can be considered as a linear sum of fundamental secondary structural elements. The percentage of every element is related to the spectral intensity. The molar absorptivity of $\mathrm{C}=\mathrm{O}$ stretching vibration for each secondary structural element is same.

FTIR studies of proteins and peptides have been used in identifying characteristic frequencies and determination of relation to structures of protein molecule.

Venyaminov, S. Y. et al. [12] and Chiragadze, Y. N. et al. [13] have studied some amino acid residues such as arginine, asparagine, glutamine, aspartic and glutamic acids, lysine, tyrosine, histidine and phenylalanine. These residues have intensive absorption in the amide region using $\mathrm{H}_{2} \mathrm{O}$ solution to dissolve these residues. The quantitative estimation of amino acid side chain groups allows us to more refined analysis of secondary structures of polypeptides and proteins.

Kanagathara, N. et al. [14] have studied FTIR and UV-visible spectral study on normal blood samples and found that the characteristic bands on infrared spectrum in the frequency ranges $3100 \mathrm{~cm}^{-1}-2800 \mathrm{~cm}^{-1}, 1800$ $\mathrm{cm}^{-1}-1400 \mathrm{~cm}^{-1}$ and $1400 \mathrm{~cm}^{-1}-900 \mathrm{~cm}^{-1}$ for lipid, protein and carbohydrates respectively. Vibration band assignment has been also carried out on infrared spectrum of sera on comparing the position relative intensity and shape of the bands with the bands of related molecules. They have also detected a considerable difference in infrared absorbance of these biomolecules.

Gunasekaran, S. et al. [15] have studied FTIR spectral study on jaundice blood samples before and after treatment and found that on the interpretation of the spectra of jaundice blood samples provide a direct link to 
the assessment of the state of health of healthy person with respect to jaundice patients. They have also found that there are two most intense bands in the spectra of sera samples are amide I and amide II bands. These bands in spectrum of bilirubin are very strong and intense.

Gunasekaran, S. et al. [16] have studied FTIR and UV-visible study on normal and jaundice blood samples. They have shown that the lower wave number region starts with a very intensive amide I band at $1652 \mathrm{~cm}^{-1}$. The deformation motion of the N-H group has dominant contribution in amide II band at $1543 \mathrm{~cm}^{-1}$. There are few bands at $1455 \mathrm{~cm}^{-1}, 1403 \mathrm{~cm}^{-1}$ and $1314 \mathrm{~cm}^{-1}$ are less intensive and belong to additional vibrations of amino groups and alkyl side chains in proteins. The important band amide III for secondary structure determination is found in the region near $1300 \mathrm{~cm}^{-1}$.

Sankari, S. et al. [17] have studied serum immunoglobulins IgA, IgG and IgM of affected blood samples of multiple myeloma. They have observed that the spectral features were same as expected but the amount of absorption was decreased in IgG samples than that of normal healthy controls. They have measured five intensities ratio parameters such as $R_{1}, R_{2}, R_{3}, R_{4}$ and $R_{5}$ among the prominent absorption peaks due to proteins. Authors concluded that the IgG and IgM have shown a decreasing pattern of level of absorption of the vibrational peaks whereas IgA exhibits increased pattern.

Choo, L. P. et al. [18] have studied neuritic plaques and neurofibrillary tangles in human brain and identification of these with FTIR spectroscopy. They have found a band at $1615 \mathrm{~cm}^{-1}$ in Alzheimer's diseased sample. This band is a characteristic of a protein in an aggregated state. The band arises from Beta A-4 amyloid protein. They have 18q-grey matter spectra which showed increase intensity of phosphate bands in accordance with known hyperphorylation of proteins found in neurofibrillary tangles.

Shaw, R. A. et al. [19] have studied arthritis using synovial fluid as specimen for infrared spectrum analysis. Synovial fluid shows infrared absorption in $400 \mathrm{~cm}^{-1}$ to $2500 \mathrm{~cm}^{-1}$ range of frequencies. They have suggested that the near infrared spectrum of synovial fluid is sufficient to allow diagnosis of the disease affecting the joint from which the sample was drawn.

Tarbit, I. et al. [20] have examined amino acid composition of brain tissue and proved a useful examination. The change in $\gamma$-aminobutryic acid concentration was also found. It was highly increased in case of arginine. Authors have suggested that the trends toward increasing free amino acid may be related to an elevated rate of proteolysis.

Mann, D. M. A. et al. [21] have found a reduction in RNA and the volume of the nucleus indicate a decline in protein synthesis.

Benezzeddine, B. L. et al. [22] have studied validation for quantification of immunoglobulins by Fourier transform infrared spectrometry and found that there was a significant correlation between FTIR predicted concentration and the concentration obtained with the clinical reference method.

Smith, K. F. et al. [23] have studied $\beta$-sheet secondary structure of the trimeric globular domain of Clq of complement and collagen type VII and X using this spectroscopy. The Clq plays a key role in the recognition of immune complexes, due to this fact there is an initiation in the classical pathway of the complement activation. They have found that the spectrum of Clq showed two major bands at $1655 \mathrm{~cm}^{-1}$ and other at $1661 \mathrm{~cm}^{-1}$. The spectra of collagen showed a major band at $1659 \mathrm{~cm}^{-1}$. Two minor bands were also found at $1632 \mathrm{~cm}^{-1}$ and 1682 $\mathrm{cm}^{-1}$. They have concluded that the Clq globular heads contain primarily $\beta$-sheet structure.

Petibois, C. et al. [24] have studied plasma protein contents. They have analyzed albumin, glucose, fibrinogen, IgG(2), lactate, IgG(1), alpha(1)-antitrypsin, alpha(2)-macroglobulin, transferin, appolipoprotein (Apo)-A(1), urea, Apo-B, IgM, Apo C(3), IgA, IgG(4), IgG(3), IgD haptoglobin and alpha(1)-acid glycoprotein. The results were matched with the results obtained by other clinical methods.

Pistorius, A. M. et al. [25] have monitored biomass composition from microbiological sources by using this sophisticated technique. They have determined protein, lipids, carbohydrate content, creatine phosphokinase, egg phosphatidyl choline and starch hydrolysate. Protein content was found at amide II band about $1545 \mathrm{~cm}^{-1}$. Lipid content was determined due to C-H stretching vibrational frequencies between $2984 \mathrm{~cm}^{-1}$ and $2780 \mathrm{~cm}^{-1}$. Carbohydrate content was determined using this methodology and found that due to $\mathrm{C}-\mathrm{O}$ and $\mathrm{C}-\mathrm{O}-\mathrm{C}$ stretching band, at $1180 \mathrm{~cm}^{-1}$ and $1133 \mathrm{~cm}^{-1}$.

Karadenizli, A. et al. [26] have applied this technique to classify slime from staphylococci. They have succeeded in classification according to species three of four S. aureus samples and four of five S. epidermidis samples.

Toubas, D. et al. [27] have studied this spectroscopy in medical mycology to differentiate Candida. They have 
used 3 Candida species such as C. albieans, C. glabrate and C. krusei and succeeded in discrimination with each other. These are some types of fungal infections.

Jiarong, W. et al. [28] have conformed protein secondary structure in some species of Fusarium cells under the influence of growth cultures and bodies. They have obtained the percentages of secondary structure components such as $\alpha$-helix, $\beta$-sheet, turn, random coil and $\beta$-anti parallel. There was a structural diversity among different Fusarium species. Cell structure of fungi can also be studied with this sophisticated technique.

Issaksson, H. et al. [29] have used this spectroscopy to understand altered bone turnover in renal osteodystrophy. This dystrophy alters metabolic activity and remodeling rate of bone and may lead to different bone composition. They have measured ratios of phosphate to amide I, carbonate to phosphate and carbonate to amide I. Collagen cross link ratio was also measured.

Becker, K. et al. [30] have studied the dynamic changes in staphylococcus aureus small colony variants. They have used first derivative infrared spectra to calculate spectral distances; hierachical clustering based on spectral information resulted in a dendrogram with clear cut discrimination between Scvs and normal phenotypes.

Zwielly, A. et al. [31] have studied human colonic tissues and reported that the FTIR spectroscopy is a tool to discriminate the benign, premalignant and colonic polyps.

Dimitrova, M. et al. [32] have studied breast cancer tumors with the application of FTIR and reported that the quantitative analysis of the secondary structure in the amide I region showed different ratio of $\alpha$-helix, $\beta$-sheet, $\beta$-turns, random coils. They have found bands in the case of muco-carcinoma in consequence of muco-glyeoprotein creation, which are characteristic bands $3400 \mathrm{~cm}^{-1}$ and $1300 \mathrm{~cm}^{-1}$.

Petibois, C. et al. [33] have studied plasma protein contents with the help of this spectroscopy. They have analyzed plasma proteins, lactate and urea and reported that their results agreed with obtained by clinical methods. They have also reported that the bands are found for different fractions of immunoglobulin $\mathrm{G}$ as $802 \mathrm{~cm}^{-1}$ for $\operatorname{IgG}_{1}, 1087 \mathrm{~cm}^{-1}$ and $982 \mathrm{~cm}^{-1}$ for IgG, $1185 \mathrm{~cm}^{-1}$ for IgG 3 and $893 \mathrm{~cm}^{-1}$ for $\operatorname{IgG}_{4}$.

Cooper, E. A. et al. [34] have studied protein structure with the help of this spectroscopy. They have given their views such as this technique is very sensitive to the backbone, amide arrangement of peptide and protein molecules. The amide I band is a peculiar band which provides the most insight into secondary structure under biologically relevant conditions.

Buijs, J. et al. [35] have studied change in secondary structure of adsorbed IgG and F(ab') $)_{2}$. They have shown that the adsorbed amounts decrease with an increasing net charge density on the protein for IgG. This decrease is correlated to a reduction in the $\beta$-sheet content which suggested that IgG molecules adsorb in a less compact conformation. The $\mathrm{F}(\mathrm{ab})_{2}$ fragments have a higher structural stability toward adsorption than whole IgG molecule.

Marco, V. D. W. et al. [36] have studied protein conformation with the help of this technique. They have reported that changes in the amide bands in Fourier transform infrared spectra of proteins are attributed to alterations in protein secondary structure.

Their study revealed that the amid I, II and III, bands differ in their sensitivities to change in protein conformation. The bands in the region $1620 \mathrm{~cm}^{-1}$ to $1630 \mathrm{~cm}^{-1}$ and $1685 \mathrm{~cm}^{-1}$ to $1695 \mathrm{~cm}^{-1}$ were found in amide I region of aggregated protein spectra. No such type of absorption seen in amide II and III region. They concluded that amide I can be used to distinguish between intra and intermolecular $\beta$-sheet conformation.

Mackanos, M. A. et al. [37] have studied this spectroscopy for prostate cancer detection. They have found that biochemical changes associated with prostate cancer could be discriminated to classify confined and locally invasive prostate cancers.

Ebenstein, D. M. e. al. [38] have studied nanomechanical properties of calcification, fibrous, and hematoma from atherosclerotic plaques. They have used FTIR spectroscopy to quantify the amount of mineral and lipid in each tissue region. They have also shown that the stiffness of plaque tissue increases with increasing mineral content.

Jiang, Z. et al. [39] have studied urinary composition by infrared spectroscopy. They have shown that $37.4 \%$ patients were pure and $33.9 \%$ were most frequent calcium oxalate and calcium phosphate were $2.7 \%$ only. They concluded that pure stone was calcium oxalate.

Sossé, D. P. et al. [40] have studied gall stone using this technique and found that most gall stones were composed of pigment stones with relative large proportion of cholesterol stones. They have revealed that this technique is a method to determine quality and quantity of biochemical components of gall stones. 
Renuga, D. T. S. et al. [41] have studied renal failure patients blood samples for FTIR analysis. They have calculated internal standard ratio among some selected specific absorption peaks. Their data were well supported by the clinical findings.

Haas, S. L. et al. [42] have studied myocardial infarction and heart failure. They have used artificial neural network algotherim with FTIR experimental findings in heart failure and myocardial infarction and concluded that FTIR spectroscopy is a tool to diagnose heart diseases from serum samples.

Malins, D. C. et al. [43] have studied progressive alterations in breast DNA with the help of this spectroscopy. They have used base model data with their spectral data and found that there is a high correlation between these two. This correlation is a predictor of breast cancer. Their results also suggest therapeutic strategies for potentially reversing the extent of DNA damage may be useful in disease prevention and treatment.

Elliolt, A. et al. [44] have studied structure of synthetic polypeptides. They have used methyl ester and found that components of $\mathrm{C}=\mathrm{O}$ band with $\alpha$ and $\beta$ forms at $1658 \mathrm{~cm}^{-1}$ and $1629 \mathrm{~cm}^{-1}$ respectively. The N-H deformation mode has two frequencies $1527 \mathrm{~cm}^{-1}$ and $1550 \mathrm{~cm}^{-1}$ showed a parallel and perpendicular dichroism corresponding to the $\beta$ and $\alpha$-forms.

Timasheff, S. N. et al. [45] have studied infrared investigation of the secondary structure of $\beta$-lactogobulins. They have shown that the amide I band due to $\mathrm{C}=\mathrm{O}$ stretching is characterised by a sharp maxima at $1632 \mathrm{~cm}^{-1}$ and by pronounced skewness on the high frequency side, with weak but reproducible shoulders close to 1650 $\mathrm{cm}^{-1}$ and $1685 \mathrm{~cm}^{-1}$. They have also found that the centre of amide II band was $1530 \mathrm{~cm}^{-1}$. Their results indicate a prevalence of $\beta$ conformation in the native structure of this protein.

Pauling, L. et al. [46] have studied configurations of polypeptide chains with favoured orientations around single bands. They have shown that 5.1 residue helix is a less stable configuration of polypeptide chains than the 3.7-residuce helix.

Susi, H. et al. [47] have studied protein structure and applied second derivative method to Fourier transform spectra of proteins such as ribonuclease A, hemoglobin and $\beta$-lactogobulins A and obtained spectra at $1350 \mathrm{~cm}^{-1}$ to $1800 \mathrm{~cm}^{-1}$. They have also shown that observed peaks were associated with the $\alpha$-helix, $\beta$-strands and turns.

Krimm, S. et al. [48] have studied intermolecular interaction effects in the amide I vibrations of $\beta$ polypeptides. The modification of the perturbation treatment of amide I modes has important implications for the analysis of peptide conformations in proteins by FTIR spectroscopy.

Miyazawa, T. [49] studied perturbation treatment of the characteristic vibrations of polypeptide chains in various configurations. He had pointed out that the amide I and II frequencies were derived in terms of adjacent group interactions as well as interchain and interchain hydrogen bonding interactions. Each characteristic vibration of the amide group gives rise to parallel and perpendicular bands. The parallel bands of $\alpha$-helix of poly- $\gamma$ benzyl-L-glutamate were found at $1650 \mathrm{~cm}^{-1}$ (amide I), and $1516 \mathrm{~cm}^{-1}$ (amide II). The perpendicular bands were observed at $1652 \mathrm{~cm}^{-1}$ and $1546 \mathrm{~cm}^{-1}$ as amide I and II band respectively.

Byler, D. M. et al. [50] have studied secondary structure of proteins. They have studied 21 globular proteins in $\mathrm{D}_{2} \mathrm{O}$ solution. Proteins are frequently referred to as having a certain fraction of helical structure and a certain fraction of extended $\beta$ structure. The secondary structure of proteins in infrared spectrum is reflected by the amide I and amide II bands. Amide I absorbs around $1620 \mathrm{~cm}^{-1}$ to $1690 \mathrm{~cm}^{-1}$. This band is associated with the stretching vibrations of peptide carbonyl groups. They have found that immunoglobulin $\mathrm{G}$ has $76 \% \beta$ structure and $9 \% \alpha$-helix. The protein such as $\alpha$-actalbumin has $41 \% \beta$ structure with $33 \% \alpha$-helix, while $\beta$-lactogobulins has $50 \% \beta$ structure with $10 \% \alpha$-helix.

Mantsch, H. H. et al. [51] have studied resolution enhancement of the infrared spectra of biomolecules. Living things are composed of lifeless molecules. Biomolecules conform all the physical and chemical laws on isolation and individually examination. Biomolecules describe the behavior of inanimate matter. The use of infrared spectroscopy to study biomolecules in their natural aqueous environment has lagged behind that of other spectroscopic techniques. Large width of the individual absorption bands leads to highly complex band contours due to the overlap of several bands. This problem of overlapping has been solved by using FTIR spectroscopy to obtain information of biomolecules.

Proteins constitute the largest fraction of living matter in all types of cells. Most proteins serve as structural elements in cells and tissues. Many other biological functions are served by proteins, which are most versatile of all biomolecules.

Immunoglobulin $\mathrm{G}$ is a globular protein. 


\section{Materials and Methods}

Blood samples of the epileptic children, migraineous, paralytic, Alzheimer's disease and muscular dystrophy patients along with normal healthy controls were collected from the Department of Neurology, I.H.B.A.S., New Delhi after the approval of ethical committee of the hospital. $10 \mathrm{ml}$. of freshly drawn blood was collected in siliconised screw capped test tubes. Separation of IgG was done by protein A sepharose method [52].

Samples were prepared for infrared spectroscopic measurements by taking about $1 \mathrm{mg}$ of the human IgG which has been prepared in the Biotechnology laboratory of our college and $100-150 \mathrm{mg}$ of $\mathrm{KBr}$ grinded together, finally dried to remove moisture and pressed at elevated temperature under high pressure into a small disc. A clear pellet is obtained. The infrared spectra of prepared samples were recorded in the range from 400 $\mathrm{cm}^{-1}$ to $4000 \mathrm{~cm}^{-1}$ with single beam Fourier transform infrared spectrophotometer, Perkin Elemer Model-1710. This instrument has the following units and features. IR source which had temperature established ceramic source operating at $1400 \mathrm{~K}$. The abscissa accuracy and ordinate precision are $0.01 \mathrm{~cm}^{-1}$ and $0.1 \% \mathrm{~T}$, respectively. This instrument has a resolution of $1 \mathrm{~cm}^{-1}$ to $64 \mathrm{~cm}^{-1}\left[1 \mathrm{~cm}^{-1}\right.$ with a memory option fitted]. The ambient temperature and relative humidity are $15^{\circ} \mathrm{C}$ to $35^{\circ} \mathrm{C}$ and $75 \%$ max, respectively. There are three units, which are given here: 1) centre processing unit 2) cathode ray tube and 3) fast recovery deuterated triglyceride sulphate detector.

\section{Results}

Typical FTIR spectra of different diseases such as epilepsy, migraine, paraplegia, DMD and Alzheimer's disease with normals are shown in Figures 3 to 8.

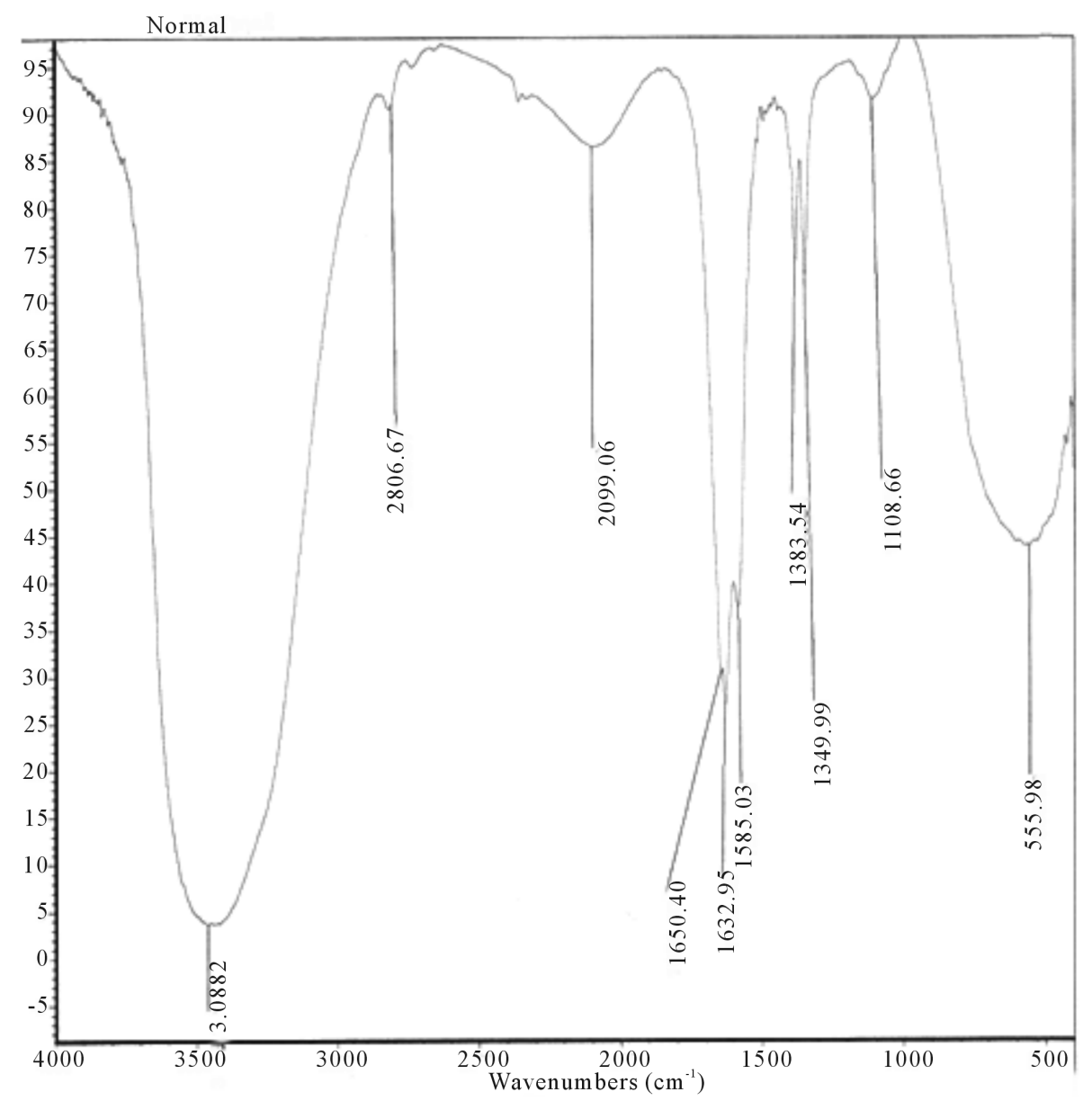

Figure 3. FTIR spectrum of normal sample. 


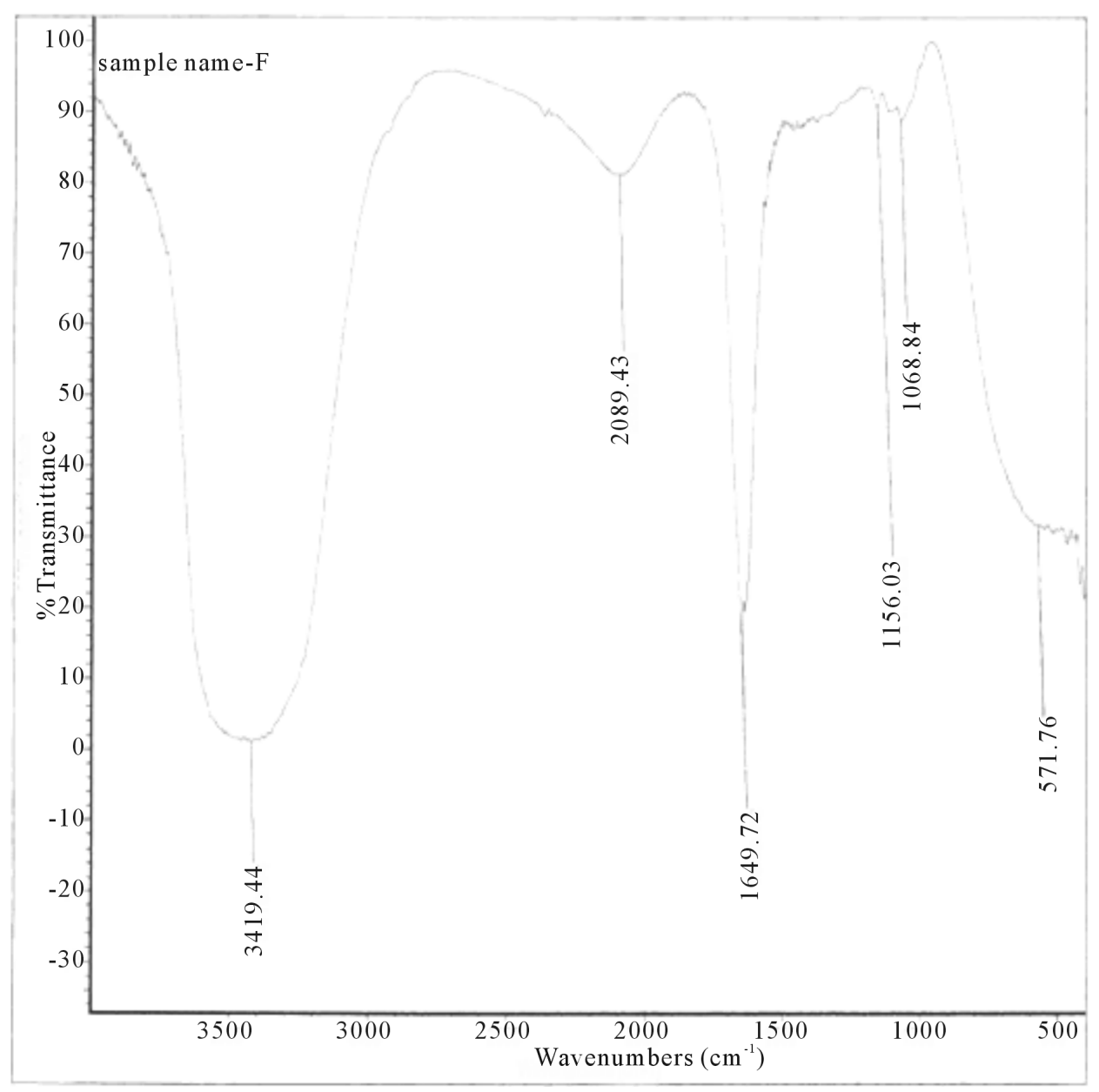

Figure 4. FTIR spectrum of paralytic sample.

Comparative chart of the vibrational frequencies and force constants with probable assignment obtained from the different spectra of IgG of diseased and normal healthy persons is given here in Table A1 in Appendix. We are giving here some of the main features of infrared band present in the protein structure in Table A2 in Appendix. We are showing here important features of infrared band present in protein structure such as immunoglobulin G of the present work in Table A3 in Appendix. We are giving here amide I band frequency and assignments to the secondary structure of proteins by Dong, A. et al. [53] in Table A4 in Appendix. We are giving here characteristic side chain frequencies of amino acid residues by Krimm, S. et al. [9] in Table A5 in Appendix.

\section{Discussion}

Abaturov L. V. et al. [54] have reported the observed frequencies of four amide bands of IgG, its peptide chains and proteolytic fragments. The frequencies and the shape of the amide bands of sulfonated IgG and F(ab') ${ }_{2}$ fragment were identical to those of the complete molecule. Position of the band maximum e.g. namely amide I, amide II, amide A and amide B in IgG, light chain of IgG and $\mathrm{F}_{\mathrm{ab}}$ fragments of IgG have been found to be 1644 $\mathrm{cm}^{-1}, 1550 \mathrm{~cm}^{-1}, 3295 \mathrm{~cm}^{-1}$ and $3055 \mathrm{~cm}^{-1}$ respectively.

Amide A and Amide I bands are intact and found in all diseased and normal samples. Amide II band is found in two cases of paralysis and one case of epilepsy and migraine. This band was absent in DMD, Alzheimer's disease and controls. Amide IV band is found in some cases of DMD, Alzheimer's disease and normal samples only. This band is absent in epilepsy, migraine and paralysis samples. Amide V band is found in some cases of paralysis and normal samples only. No trace of this band was found in epilepsy, migraine, DMD and Alzhei- 


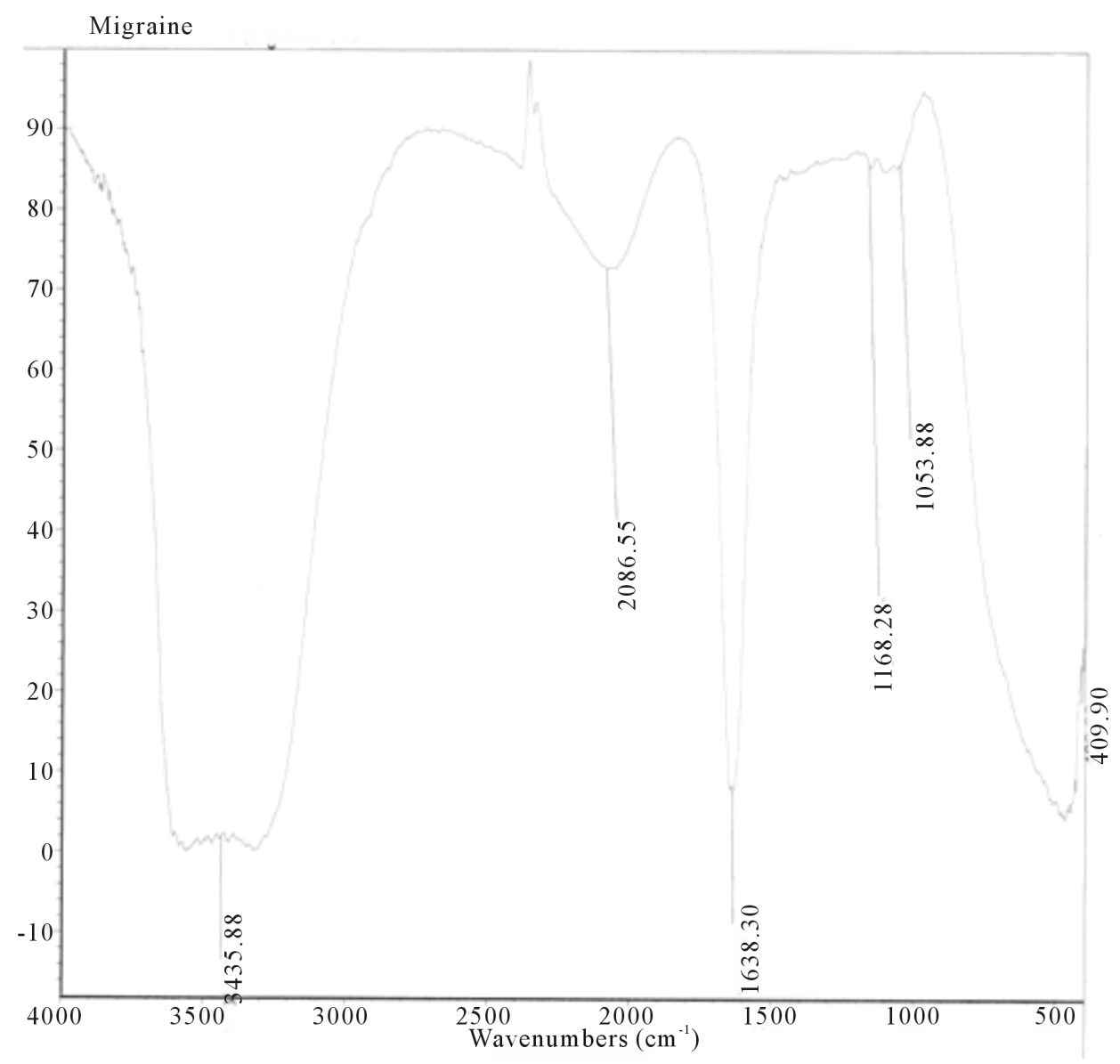

Figure 5. FTIR spectra of migraineous sample.

mer's disease cases.

Amide VI band is found in two case of Alzheimer's disease and normals. Amide VI band is absent in epilepsy, migraine, paralysis and DMD also. Carbide compound is found in paralysis, Alzheimer's disease, DMD and normals only. This compound was absent in epilepsy and migraine samples. Hydrocarbon $(\mathrm{C}-\mathrm{H})$ band is found in paralysis, Alzheimer's disease and normals only. This band is absent in DMD, epilepsy and migraine. Peroxide compound is found in all the diseases and normals. On the bases of FTIR findings we have found some bands which are completely absent in diseases compared to normal healthy persons and some bands are found in all the cases. We can say that the structure of IgG was not completely disturbed and partially damaged and many other methods of different techniques of science may be applied to maintain the structure of IgG. Some clinical and medicinal procedures may be fruitful for the safe recovery of the structure. Now further directions of research are needed to study more. The complex shape and asymmetry of Amide I band are indications of high heterogenicity of the secondary structure of IgG. The maxima of this band $\left(1644 \mathrm{~cm}^{-1}\right)$ arises due to irregular conformation and the shoulder $\left(1637 \mathrm{~cm}^{-1}\right)$ observed with the better resolution appears due to $\beta$-structure.

The inflexion at $1665 \mathrm{~cm}^{-1}$ shows the presence of an irregular and $\beta$-conformations as the major elements of the secondary structure of IgG. The band frequencies of the papain fragments of IgG are almost identical to the intact IgG molecule. However, we notice a little difference in the shape of the amide I band. This band possesses greater half-width in the infrared spectrum of the $\mathrm{F}_{\mathrm{c}}$ fragment; compared to the full IgG and the $\mathrm{F}_{\mathrm{ab}}$ fragments. The shape of the amide II band in the infrared spectra of the $\mathrm{F}_{\mathrm{ab}}$ and $\mathrm{F}_{\mathrm{c}}$ fragments is very near to the full IgG. There are no strong differences in the position and in the shape of the amide bands of IgG as compared with both of the papain fragments.

The technique of spectroscopy has used for study the secondary structures of polypeptides and proteins. Krimm, S. et al. [9] have given a proof of nine characteristic vibrational bands or group frequencies that arise 


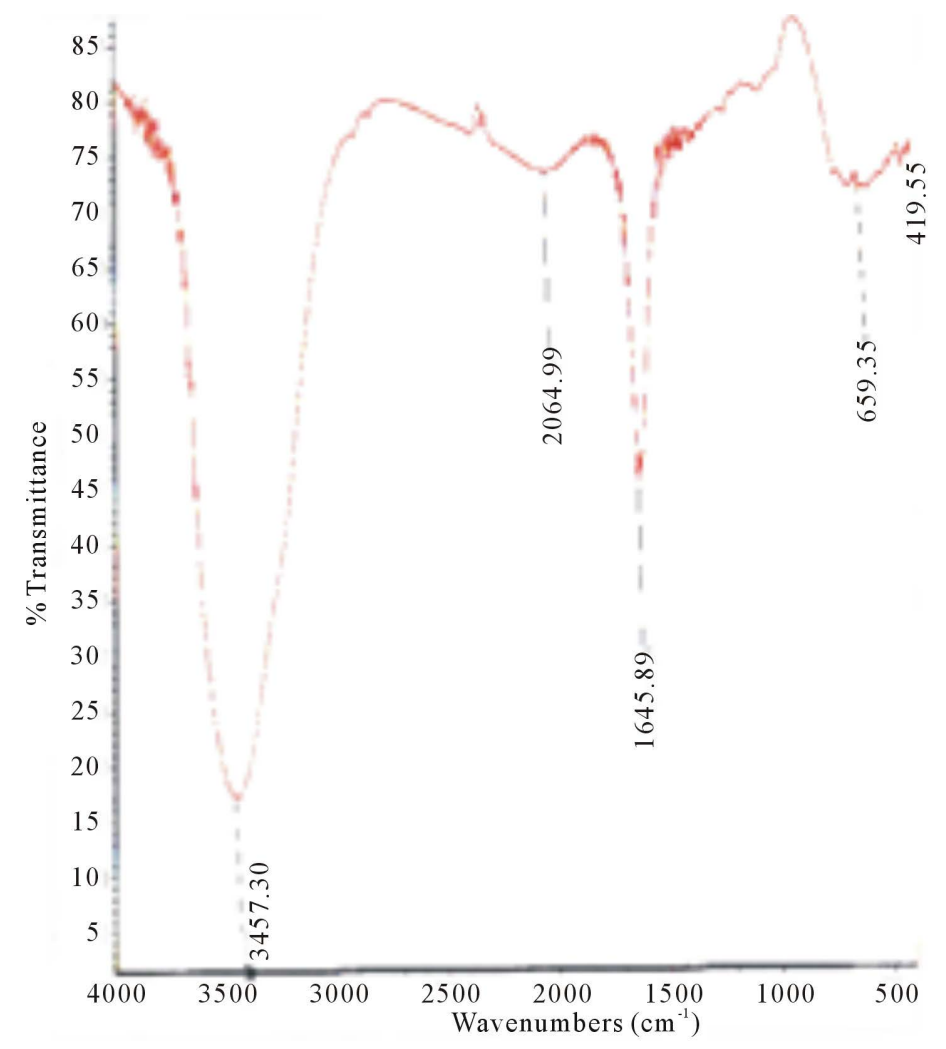

Figure 6. FTIR spectrum of epileptic sample.

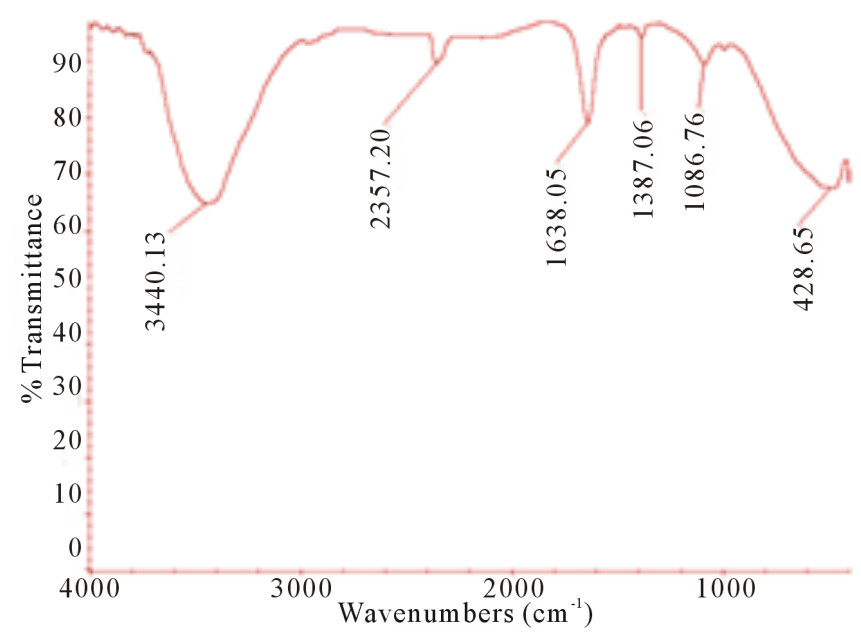

Figure 7. FTIR spectrum of Duchenne muscular dystrophic sample.

from the amide groups of protein. Among them, the amide I band $\left(1700 \mathrm{~cm}^{-1}\right.$ to $\left.1620 \mathrm{~cm}^{-1}\right)$ is due to $\mathrm{C}=\mathrm{O}$ stretching vibration of the peptide linkages that constitute the backbone structure. The another intense absorption band is amide II band $\left(1600 \mathrm{~cm}^{-1}\right.$ to $\left.1500 \mathrm{~cm}^{-1}\right)$ due to an out-of-phase combination of N-H in plane bending and C-N stretching vibrations of peptide groups has been used for determination of protein structures. There is a peculear feature is high sensitivity to small variations in molecular geometry and hydrogen bonding makes amide I band uniquely very useful for analyzing protein secondary structures and monitoring the conformational changes in proteins that involve secondary structure. Each type of secondary structure gives rise to a different $\mathrm{C}=\mathrm{O}$ stretch frequency in the amide I region of the infrared spectra. 


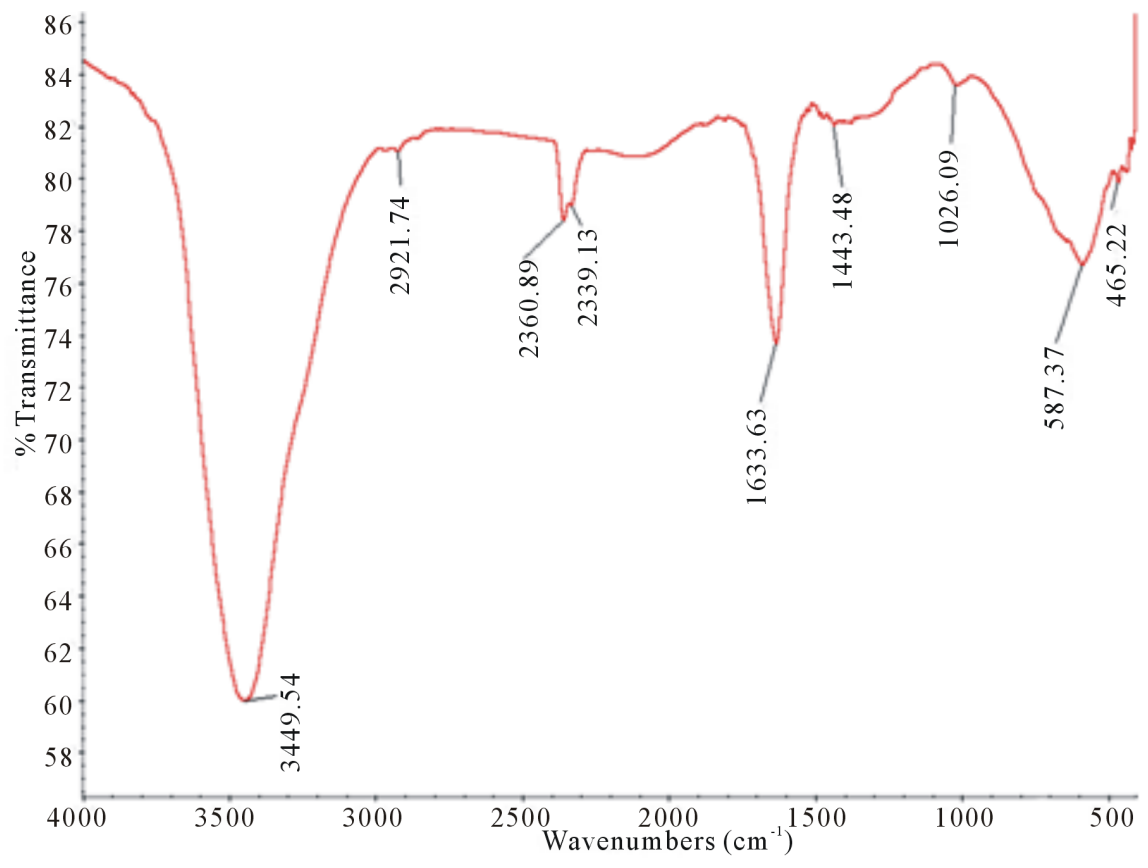

Figure 8. FTIR spectrum of Alzheimer's disease sample.

\section{Conclusions}

Some amino acid residues, especially arginine, asparagines, glutamine, asparatic and glutamic acids, lysine, tyrosine, histidine and phenylaline have very fast absorption in the amide band region.

Many diseases generate specific changes in the metabolic pattern of blood or other body fluids. These changes may produce particular spectroscopic indications, which can be used for identification and classification of the diseases in seconds to minutes.

In the present work we have succeeded in identifying the basic atomic level transformations occurring in different neurological disturbances. It is possible, on the basis of our investigations to use this technique for differential diagnosis of the various pathological disorders and to some extent the stage of the disease. It has already been pointed out that the infrared spectra exhibit the presence of specific bands peculiar to a particular disease such as epilepsy, migraine, headache, paraplegia, Alzheimer's disease and muscular dystrophy as compared to the normal samples.

The FTIR experimental findings show that the stability of the secondary structure in these neurological perturbations is completely disturbed.

\section{Acknowledgements}

The authors are thankful to Dr. P. K. Saxena, Principal, D. A. V. College, Muzaffarnagar for providing the facility of doing work. We are also thankful to Dr. V. N. Mishra, Associate Professor, I.H.B.A.S., New Delhi, for arranging the blood samples of the diseased and healthy controls. Our thanks go to Dr. Manju Chauhan, Head, Department of Biosciences, D. A. V. College, Muzaffarnagar for providing the facilities of purification of immunoglobulin G from the sera of different blood samples of the human disorders. One of the authors S.K. is thank full to University Grants Commission, New Delhi, INDIA for granting minor research project. Reference No. F.8-2(170)/2011(MRP/NRCB).

\section{References}

[1] Mark, B. (2002) Fourier Transform Infrared Spectroscopy. In: Practicing Oil Analysis-Fourier Transform Infrared Spectroscopy-Machinery Lubrication, Noria Publication, Tula, 1-4.

[2] Whiffen, D.H. (1972) Infrared Spectroscopy. In: Spectroscopy, 2nd Edition, John Wiley \& Sons, Inc., New York, 92-107. 
[3] Gupta, S.L., Kumar, V. and Sharma, R.C. (2007) Vibrational-Rotational Spectra (Near Infrared Spectroscopy). In: Elements of Spectroscopy, Pragati Prakashan, Meerut, 410-449.

[4] Sturat, B. (1997) Biological Applications of Infrared Spectroscopy. John Wiley \& Sons, Chichester, 25-33.

[5] Schmit, J. and Flemming, H.C. (1998) FTIR Spectroscopy in Microbial and Material Analysis. International Biodeterioration \& Biodegradation, 41, 1-11. http://dx.doi.org/10.1016/S0964-8305(98)80002-4

[6] Naumann, D. (1984) Some Ultrastructural Information on Intact, Living Bacterial Cells and Related Cell-Wall Fragments as Given by FTIR. Infrared Physics, 24, 233-238.

[7] Naumann, D., Fijala, V., Labichinski, H. and Giesbrecht, P. (1988) The Rapid Differentiation and Identification of Pathogenic Bacteria Using Fourier Transform Infrared Spectroscopic and Multivariate Statistical Analysis. Journal of Molecular Structure, 174, 165-170. http://dx.doi.org/10.1016/0022-2860(88)80152-2

[8] Ellis, D.I., Harrigan, G.G. and Goodcare, R. (2003) Its Role in Biomarker Discovery and Gene Function Analysis. In: Goodcare, R. and Harrigan, G.G., Eds., Kluwer Academic, Boston, 111-124.

[9] Krimm, S. and Bandekar, J. (1986) Vibrational Spectroscopy and Conformation of Peptides, Polypeptides and Proteins. Advances in Protein Chemistry, 38, 181-364. http://dx.doi.org/10.1016/S0065-3233(08)60528-8

[10] Movasaghi, Z., Rehman, S. and Ur Rehman, I. (2008) Fourier Transform Infrared (FTIR) Spectroscopy of Biological Tissues. Applied Spectroscopy Review, 43, 134-179.

[11] Kong, J. and Yu, S. (2007) Fourier Transform Infrared Spectroscopic Analysis of Proteins in Secondary. Acta Biochimica et Biophysica Sinica, 39, 549-559.

[12] Venyaminev, S.Y. and Kalmin, N.H. (1990) Quantitative IR Spectrophotometry of Peptides Compounds in Water $\left(\mathrm{H}_{2} \mathrm{O}\right)$ Solution, I, Spectral Parameters of Amino Acid Residue Absorption Bands. Biopolymers, 30, 1243-1257. http://dx.doi.org/10.1002/bip.360301309

[13] Chirgadze, Y.N., Fedorov, O.V. and Trushina, N.P. (1975) Estimation of Amino Acid Residue Side-Chain Absorption in Infrared Spectra of Protein Solution in Heavy Water. Biopolymers, 14, 679-694. http://dx.doi.org/10.1002/bip.1975.360140402

[14] Kanagathara, N., Thirunavukkarasu, M., Jeyanthi, C.E. and Shenabagarajan, P. (2011) FTIR and UV-Visible Spectral Study on Normal Blood Samples. International Journal of Pharmacy and Biological Sciences, 1, 74-80.

[15] Gunasekaran, S., Uthra, D., Sailatha, E. and Anita, B. (2010) FTIR Spectral Study on Jaundice Blood Samples before and after Treatment. Asian Journal of Chemistry, 22, 51-56.

[16] Gunasekaran, S. and Uthra, D. (2008) FTIR and UV-Visible Spectral Study on Normal and Jaundice Blood Samples. Asian Journal of Chemistry, 20, 5695-5703.

[17] Sankari, G., Krishnamoorthy, E., Jayakumaran, S., Gunasekaran, S., Vishnu, P.V., Subramanian, S., Subramaniam, S. and Surapaneni, K.M. (2010) Analysis of Serum Immunoglobulins Using Fourier Transforms Infrared Spectral Measurements. Biology \& Medicine, 2, 42-48.

[18] Chou, L.P., Jackson, M., Willian, C.H. and Mantsch, H.H. (1994) Alzheimer's Disease: Neuritic Plaques and Neurofibrillary Tangles in Human Brain Identified by FTIR Spectroscopy. Proceedings of SPIE 2089, 9th International Conference on Fourier Transform Spectroscopy, Calgary, 104. http://dx.doi.org./10.1117/12.166733.

[19] Show, R.A., Kotowich, S., Ecysel, H.H., Jackson, M., Thomson, G.T. and Mantsch, H.H. (1995) Arthritis Diagnosis Based upon the Near-Infrared Spectrum of Synovial Fluid. Rheumatology International, 15, 159-165. http://dx.doi.org/10.1007/BF00301774

[20] Tarbit, I., Perry, E.K., Perry, R.H., Blessed, G. and Tomlinson, B.E. (1980) Hippocampal Freo Amino Acid in Alzheimer's Disease. Journal of Neurochemistry, 35, 1246-1249. http://dx.doi.org/10.1111/j.1471-4159.1980.tb07883.x

[21] Mann, D.M.A. and Sinclair, K.G.A. (1971) The Quantitative Assessment of Lipofusion, Cytoplasmic RNA and Molecular Volume in Senile Dementia. Neuropathology and Applied Neurobiology, 4, 129-135. http://dx.doi.org/10.1111/j.1365-2990.1978.tb00553.x

[22] Benezzeddine, B.L., Cazorla, G. and Melin, A.M. (2009) Validation for Quantification of Immunoglobulins by Fourier Transform Infrared Spectra. Clinical Chemistry and Laboratory Medicine, 47, 83-90.

[23] Smith, K.F., Haris, P.I., Chapman, D., Reid, K.B. and Perkins, S.J. (1994) Beta-Sheet Secondary Structure of the Trimeric Globular Domain of Clq of Complement and Collagen Type VII, and X by Fourier Transform Infrared Spectroscopy and Averaged Structure Predictions. Biochemical Journal, 301, 249-256.

[24] Petibois, C., Cazoria, G., Cassaigne, A. and Déldris, G. (2001) Plasma Protein Contents Determined by Fourier Transform Infrared Spectrometry. Clinical Chemistry, 47, 730-738.

[25] Pistorius, A.M., De Grip, W.J. and Egerova-Zachemyuk, T.A. (2009) Monitoring of Biomass Composition from Microbiological Sources by Means of FTIR Spectroscopy. Biotechnology and Bioengineering, 103, 123-129. http://dx.doi.org/10.1002/bit.22220 
[26] Karadenizli, A., Kolayli, F. and Ergen, K. (2007) A Novel Application of Fourier Transfered Infrared Spectroscopy: Classification of Slime from Staphylococci. Biofouling, 23, 63-71.

[27] Toubas, D., Essendoubi, M., Adt, I., Pinon, J.M., Manfait, M. and Sockalingum, G.D. (2007) FTIR Spectroscopy in Medical Mycology: Applications to the Differentiation and Typing of Candel. Analytical and Bioanalytical Chemistry, 387, 1729-1737. http://dx.doi.org/10.1007/s00216-006-1005-1

[28] Tiarang, W., Liv, Y., Lan, L., Yan, G., Ming, N.I.E. and Zhou, J. (2009) Conformational Study of Protein in Some Species of Fubarium by FTIR Spectroscopy. Annals of Microbiology, 58, 169-171.

[29] Isa Ksan, H., Turunen, M.J., Rieppo, L., Saarakkala, S., Tanminen, I.S., Rieppo, J., Kröger, H. and Jurvelin, J.S. (2010) Infrared Spectroscopy Indicates Altered Bone Turnover and Remodeling Activity in Renal Osteodystrophy. Journal of Bone and Mineral Research, 25, 1360-1366. http://dx.doi.org/10.1002/jbmr.10

[30] Becker, K., Lahnam, N.A., Fegeler, W., Proctor, R.A., Peters, G. and Van Eift, C. (2006) Fourier Transform Infrared Spectroscopic Analysis Is a Powerful Tool for Studying the Synamic Changes in Staphylacoccusaureus Small-Colony Variants. Journal of Clinical Microbiology, 44, 3274-3278. http://dx.doi.org/10.1128/JCM.00847-06

[31] Zwielly, A., Mordechai, S., Sinielnikav, I., Salman, A., Bagomotny, E. and Argev, S. (2010) Advanced Statistical Techniques Applied to Comprehensive FTIR Spectra on Human Colonic Tissues. Medical Physics, 37, 1047-1055. http://dx.doi.org/10.1118/1.3298013

[32] Dimitrova, M., Ivanova, D., Karamancheva, I., Mileu, A. and Dobreu, I. (2009) Application of FTIR Spectroscopy for Diagnosis of Breast Cancer Tumors. Journal of University of Chemical Technology and Metallurgy, 44, 297-300.

[33] Petibois, C., Cazerla, G., Cassaigne, A. and Déléris, G. (2001) Plasma Protein Contents Determined by Fourier Transform Infrared Spectrometry. Clinical Chemistry, 47, 730-738.

[34] Cooper, F.A. and Knutson, K. (1995) Fourier Transform Infrared Spectroscopy Investigations of Protein Structure. Pharmaceutical Biotechnology, 7, 101-143. http://dx.doi.org/10.1007/978-1-4899-1079-0_3

[35] Buijsand, J. and Nerde, W. (1996) Changes in the Secondary Structure of Adsorbed IgG and F(ab’)2 Studied by FTIR Spectroscopy. Langmuir, 12, 1605-1613. http://dx.doi.org/10.1021/la950665s

[36] Marco, V.D., Parvez, I.H., Wim, E.H. and Daan, J.A.C. (2001) Fourier Transform Infrared Spectrometric Analysis of Protein Conformation: Effect of Sampling Method and Stress Factors. Analytical Biochemistry, 297, 160-169. http://dx.doi.org/10.1006/abio.2001.5337

[37] Mackanos, M.A. and Contag, C.H. (2009) FTIR Micro Spectroscopy for Improved Prostate Cancer Diagnosis. Trends in Biotechnology, 27, 661-663. http://dx.doi.org/10.1016/j.tibtech.2009.09.001

[38] Ebestein, D.M., Coughlin, D., Chapman, J. and Licand Pruitt, L.A. (2009) Nonmechanical Proterties of Calcification, Figrous Tissue, and Hematoma from Atherosclerotic Plaques. Journal of Biomedical Materials Research Part A, 91, 1028-1037. http://dx.doi.org/10.1002/jbm.a.32321

[39] Zhang, J., Wang, G.Z., Jiang, N., Yang, J.W., Gu, Y. and Fang, Y. (2010) Analysis of Urinary Calculi Composition by Infrared Spectroscopy: A Prospective Study of 625 Patients in Estern China. Urological Research, 38, 111-115. http://dx.doi.org/10.1007/s00240-010-0253-x

[40] Sossé, D.P., Aké, M.A., Tiahov, G., Koffi, G., CisséCamara, M., Diohan, F., Yapo, E., Kassayou, S., Peuchant, E., Essiagne, S.D. and Mannet, D. (2010) Gall Stone Biochemical Characteristics Using Fourier Transform Infrared Spectroscopy Method. Annales de Biologie Clinique (Paris), 68, 39-42.

[41] Renuga, D.T.S., Gunasekaran, S., Hudson, J.W. and Joybell, I.S.A. (2009) Analysis of Renal Failure Patients Blood Samples: Characterization and Efficacy Study. Indian Journal of Science and Technology, 2, 46-50.

[42] Haas, S.L., Möller, R., Fernandes, A., Dzeyk-Boycheva, K., Wörl, S., Hohmann, J., Hemberger, S., Elmas, E., Brökhmann, M., Bugert, P. and Backhaus, J. (2010) Spectroscopic Diagnosis of Myocardial Infarction and Heart Failure by Fourier Transforms Infrared Spectroscopy in Serum Samples. Applied Spectroscopy, 64, 262-267. http://dx.doi.org/10.1366/000370210790918508

[43] Malins, D.C., Polissar, N.L., Niohikila, K., Holmes, E.H., Gardner, H.S. and Gunselman, S.J. (1995) The Etiology and Prediction of Breast Cancer. Fourier Transform Infrared Spectroscopy Reveals Progressive Alterations in Breast DNA Leading to a Cancel-Like Phemotype in a High Proportion of Normal Woman. Cancer, 75, 503-517. http://dx.doi.org/10.1002/1097-0142(19950115)75:2<503::AID-CNCR2820750213>3.0.CO;2-0

[44] Elliott, A. and Ambrose, E.J. (1950) Structure of Synthetic Polypeptides. Nature, 165, 921-922. http://dx.doi.org/10.1038/165921a0

[45] Timasheff, S.N. and Susi, H. (1966) Infrared Investigations of the Secondary Structure of $\beta$-Lactoglobulins. Journal of Biological Chemistry, 241, 249-251.

[46] Pauling, L. and Corey, R.B. (1951) Configurations of Polyplptide Chains with Favored Orientations around Single Bonds: Two New Pleated Sheets. Proceedings of the National Academy of Sciences of the United States of America, 37, 729-740. http://dx.doi.org/10.1073/pnas.37.11.729 
[47] Susi, H. and Byler, D.M. (1983) Protein Structure by Fourier Transform Spectroscopy: Second Derivative Spectra. Biochemical and Biophysical Research Communications, 115, 391-397. http://dx.doi.org/10.1016/0006-291X(83)91016-1

[48] Krimm, S. and Yasuaki, A. (1972) Intermolecular Interaction Effects in the Amide I Vibrations of $\beta$-Poly Peptides. Proceedings of the National Academy of Sciences of the United States of America, 69, 2788-2792. http://dx.doi.org/10.1073/pnas.69.10.2788

[49] Miyazawa, T. (1960) Perturbation Treatment of the Characteristic Vibrations of Polypeptide Chains in Various Configurations. Journal of Chemical Physics, 32, 1647-1656. http://dx.doi.org/10.1063/1.1730999

[50] Byler, D.M. and Susi, H. (1986) Examination of the Secondary Structure of Proteins by Deconvolved FTIR Spectra. Biopolymers, 25, 469-487. http://dx.doi.org/10.1002/bip.360250307

[51] Mantsch, H.H., Heetor, L.C. and Tones, R.N. (1986) Resolution Enhancement of Infrared Spectra of Biological Systems. In: Clark, R.J.H. and Hester, R.E., Eds., Spectroscopy of Biological System, Advances in Spectroscopy, Vol. 13, John Willey \& Sons, New York, 16-45.

[52] Hudson, L. and Hay, F.C. (1980) Practical Immunology. 2nd Edition, Blackwell Scientific Publications, Oxford, 222.

[53] Dong, A., Huang, P. and Caughey, W.S. (1990) Protein Secondary Structures in Water from Second-Derivative Amide I Infrared Spectra. Biochemistry, 29, 3303-3308. http://dx.doi.org/10.1021/bi00465a022

[54] Abaturov, L.V., Nezlin, R.S., Vengerova, T.I. and Varshavsky Jr., M. (1969) Conformational Studies of Immunoglobulin Gand Its Sub Units by the Method of Hydrogen-Deutrium Exchange and Infrared Spectroscopy. Biochimica et Biophysica Acta, 194, 386-396. http://dx.doi.org/10.1016/0005-2795(69)90099-3 


\section{Appendix}

Table A1. FTIR spectra of IgG in normal and pathological samples. E: Epilepsy, M: Migraine, P: Paralysis, DMD: Duchenne Muscular dystrophy) and A: Alzheimer's Disease.

\begin{tabular}{|c|c|c|c|c|c|}
\hline S.N. & Wave number $\left(\mathrm{cm}^{-1}\right)$ & Type of sample & $\begin{array}{l}\text { Vibrational energy } \\
\text { (E) }\left(\mathrm{kJ} \cdot \mathrm{mole}^{-1}\right)\end{array}$ & $\begin{array}{c}\text { Force constant } \\
(\mathrm{K})\left(\mathbf{N} \cdot \mathrm{m}^{-1}\right)\end{array}$ & $\begin{array}{c}\text { Group/probable } \\
\text { assignment }\end{array}$ \\
\hline 1 & 608.70 & A & 7.28 & 20.35 & \\
\hline 2 & 1364.78 & A & 19.55 & & \\
\hline 3 & 621.74 & A & 7.43 & & \\
\hline 4 & 613.04 & A & 7.33 & & \\
\hline 5 & 521.74 & A & 7.33 & & \\
\hline 6 & 608.45 & A & 7.27 & & \\
\hline 7 & 610.13 & A & 7.29 & & \\
\hline 8 & 3453.93 & A & 41.30 & 665.4 & Amide A \\
\hline 9 & 3453.80 & A & 41.30 & 660.08 & Amide A \\
\hline 10 & 3445.49 & A & 41.20 & 657.6 & Amide A \\
\hline 11 & 3445.43 & A & 41.20 & 657.6 & Amide A \\
\hline 12 & 3449.55 & A & 41.25 & 659.2 & Amide A \\
\hline 13 & 3439.26 & A & 41.13 & 655.29 & Amide A \\
\hline 14 & 3448.42 & A & 41.24 & 658.7 & Amide A \\
\hline 15 & 3449.54 & A & 41.25 & 359.20 & Amide A \\
\hline 16 & 3446.78 & A & 41.22 & 658.16 & Amide A \\
\hline 17 & 3447.94 & A & 41.23 & 658.6 & Amide A \\
\hline 18 & 3433.69 & A & 41.06 & 653.17 & Amide A \\
\hline 19 & 3439.13 & A & 41.13 & 655.20 & Amide A \\
\hline 20 & 1632.35 & A & 19.52 & 146.40 & Amide I \\
\hline 21 & 1632.65 & A & 19.52 & 146.4 & Amide I \\
\hline 22 & 1633.47 & A & 19.52 & 146.15 & Amide I \\
\hline 23 & 1638.44 & A & 19.59 & 147.48 & Amide I \\
\hline 24 & 1637.56 & A & 19.58 & 147.32 & Amide I \\
\hline 25 & 1638.05 & A & 19.59 & 147.41 & Amide I \\
\hline 26 & 1636.32 & A & 19.57 & 147.1 & Amide I \\
\hline 27 & 1633.63 & A & 19.53 & 146.61 & Amide I \\
\hline 28 & 1637.01 & A & 19.57 & 147022 & Amide I \\
\hline 29 & 1631.71 & A & 19.51 & 146.27 & Amide I \\
\hline 30 & 1632.90 & A & 19.52 & 146.4 & Amide I \\
\hline 31 & 717.39 & A & 8.57 & 28.27 & Amide IV \\
\hline 32 & 752.17 & A & 8.99 & 31.08 & Amide IV \\
\hline 33 & 700.00 & A & 8.37 & 26.92 & Amide IV \\
\hline 34 & 739.13 & A & 8.83 & 30.01 & Amide IV \\
\hline 35 & 717.39 & A & 8.57 & 28.27 & Amide V \\
\hline 36 & 587.37 & A & 18.95 & 7.02 & Amide VI \\
\hline 37 & 704.35 & A & 8.42 & 27.25 & Amide VI \\
\hline 38 & 1443.48 & A & 17.26 & 735.9 & $\mathrm{C}=\mathrm{C}$ \\
\hline 39 & 1439.13 & A & 17.21 & 731.5 & $\mathrm{C}=\mathrm{C}$ \\
\hline
\end{tabular}




\section{Continued}

\begin{tabular}{|c|c|c|c|c|c|}
\hline 40 & 1391.30 & A & 16.63 & 683.6 & $\mathrm{C}=\mathrm{C}$ \\
\hline 41 & 1482.61 & A & 17.73 & 776.3 & $\mathrm{C}=\mathrm{C}$ \\
\hline 42 & 1434.78 & A & 17.15 & 727.02 & $\mathrm{C}=\mathrm{C}$ \\
\hline 43 & 2921.74 & A & 34.94 & 463.87 & $\mathrm{C}-\mathrm{H}$ \\
\hline 44 & 2856.52 & A & 34.16 & 443.39 & $\mathrm{C}-\mathrm{H}$ \\
\hline 45 & 2847.83 & A & 34.06 & 440.70 & $\mathrm{C}-\mathrm{H}$ \\
\hline 46 & 2852.17 & A & 34.11 & 442.0 & $\mathrm{C}-\mathrm{H}$ \\
\hline 47 & 1869.57 & A & 22.36 & 193.6 & $\mathrm{O}-\mathrm{H}$ \\
\hline 48 & 1878.26 & $\mathrm{~N}$ & 22.46 & 191.7 & $\mathrm{O}-\mathrm{H}$ \\
\hline 49 & 1108.70 & A & 13.26 & 578.83 & Peroxide \\
\hline 50 & 980.84 & DMD & 11.73 & - & \\
\hline 51 & 986.89 & DMD & 11.80 & - & \\
\hline 52 & 482.65 & DMD & 5.77 & - & \\
\hline 53 & 469.02 & DMD & 5.60 & - & \\
\hline 54 & 464.08 & DMD & 5.55 & - & \\
\hline 55 & 471.55 & DMD & 5.63 & - & \\
\hline 56 & 464.28 & DMD & 5.55 & - & \\
\hline 57 & 1387.06 & DMD & 16.58 & & \\
\hline 58 & 3440.13 & DMD & 41.14 & 650.18 & Amide A \\
\hline 59 & 3449.41 & DMD & 41.25 & 653.69 & Amide A \\
\hline 60 & 3448.74 & DMD & 41.24 & 653.44 & Amide A \\
\hline 61 & 3446.49 & DMD & 41.22 & 652.59 & Amide A \\
\hline 62 & 3448.28 & DMD & 41.24 & 653.27 & Amide A \\
\hline 63 & 3459.04 & DMD & 41.25 & 657.35 & Amide A \\
\hline 64 & 3460.75 & DMD & 41.39 & 658.00 & Amide A \\
\hline 65 & 3445.90 & DMD & 41.21 & 652.37 & Amide A \\
\hline 66 & 1638.05 & DMD & 19.59 & 147.41 & Amide I \\
\hline 67 & 1633.44 & DMD & 19.53 & 146.58 & Amide I \\
\hline 68 & 1642.76 & DMD & 19.64 & 148.26 & Amide I \\
\hline 69 & 1637.60 & DMD & 19.58 & 147.33 & Amide I \\
\hline 70 & 1638.11 & DMD & 19.59 & 147.42 & Amide I \\
\hline 71 & 1640.26 & DMD & 19.61 & 147.81 & Amide I \\
\hline 72 & 1640.66 & DMD & 19.62 & 147.88 & Amide I \\
\hline 73 & 660.17 & DMD & 7.89 & 23.04 & Amide IV \\
\hline 74 & 666.71 & DMD & 7.97 & 24.44 & Amide IV \\
\hline 75 & 664.35 & DMD & 7.94 & 24.21 & Amide IV \\
\hline 76 & 666.04 & DMD & 7.96 & 24.22 & Amide IV \\
\hline 77 & 556.17 & DMD & 6.65 & 16.99 & Amide VI \\
\hline 78 & 1380.17 & DMD & 16.50 & 672.79 & $\mathrm{C}=\mathrm{C}$ \\
\hline 79 & 1385.06 & DMD & 16.56 & 677.57 & $\mathrm{C}=\mathrm{C}$ \\
\hline 80 & 1384.06 & DMD & 16.55 & 676.59 & $\mathrm{C}=\mathrm{C}$ \\
\hline 81 & 1383.99 & DMD & 16.55 & 676.52 & $\mathrm{C}=\mathrm{C}$ \\
\hline 82 & 1383.82 & DMD & 16.55 & 676.54 & $\mathrm{C}=\mathrm{C}$ \\
\hline
\end{tabular}




\section{Continued}

\begin{tabular}{|c|c|c|c|c|c|}
\hline 83 & 1384.56 & DMD & 16.55 & 677.08 & $\mathrm{C}=\mathrm{C}$ \\
\hline 84 & 1384.30 & DMD & 16.55 & 676.83 & $\mathrm{C}=\mathrm{C}$ \\
\hline 85 & 1086.76 & DMD & 12.99 & 556.22 & Peroxides \\
\hline 86 & 1077.65 & DMD & 12.88 & 546.93 & Peroxides \\
\hline 87 & 1088.23 & DMD & 13.01 & 557.73 & Peroxides \\
\hline 88 & 1077.65 & DMD & 12.88 & 546.93 & Peroxides \\
\hline 89 & 1044.22 & DMD & 12.48 & 513.53 & Peroxides \\
\hline 90 & 1005.04 & DMD & 12.02 & 475.71 & Peroxides \\
\hline 91 & 1086.55 & DMD & 12.99 & 556.01 & Peroxides \\
\hline 92 & 1090.36 & DMD & 13.04 & 559.54 & Peroxides \\
\hline 93 & 1559.59 & $\mathrm{E}$ & 18.65 & & \\
\hline 94 & 1558.67 & E & 18.64 & & \\
\hline 95 & 3450.00 & E & 41.26 & 652.22 & Amide A \\
\hline 96 & 3443.02 & E & 41.18 & 649.56 & Amide A \\
\hline 97 & 3457.30 & E & 41.35 & 654.96 & Amide A \\
\hline 98 & 3480.74 & E & 40.67 & 633.41 & Amide A \\
\hline 99 & 3461.11 & E & 41.39 & 656.41 & Amide A \\
\hline 100 & 3450.65 & E & 41.27 & 652.46 & Amide A \\
\hline 101 & 3417.49 & E & 40.87 & 639.98 & Amide A \\
\hline 102 & 3429.46 & E & 41.02 & 644.47 & Amide A \\
\hline 103 & 3390.93 & E & 40.55 & 630.07 & Amide A \\
\hline 104 & 3448.13 & E & 41.24 & 651.49 & Amide A \\
\hline 105 & 3380.04 & E & 40.42 & 626.02 & Amide A \\
\hline 106 & 3444.05 & E & 41.19 & 649.95 & Amide A \\
\hline 107 & 3455.72 & E & 41.37 & 654.36 & Amide A \\
\hline 108 & 1649.11 & E & 19.72 & 149.02 & Amide I \\
\hline 109 & 1649.46 & E & 19.72 & 149.02 & Amide I \\
\hline 110 & 1645.89 & E & 19.68 & 148.43 & Amide I \\
\hline 111 & 1650.45 & E & 19.74 & 149.26 & Amide I \\
\hline 112 & 1650.51 & E & 19.74 & 149.27 & Amide I \\
\hline 113 & 1649.85 & E & 19.73 & 149.15 & Amide I \\
\hline 114 & 1651.99 & E & 19.75 & 149.54 & Amide I \\
\hline 115 & 1650.46 & E & 19.74 & 149.26 & Amide I \\
\hline 116 & 1650.06 & E & 19.73 & 149.19 & Amide I \\
\hline 117 & 1649.91 & E & 19.73 & 149.16 & Amide I \\
\hline 118 & 1649.95 & E & 19.73 & 149.17 & Amide I \\
\hline 119 & 1558.86 & E & 18.64 & 133.15 & Amide II \\
\hline 120 & 1073.30 & E & 12.83 & 542.69 & Peroxide \\
\hline 121 & 1086.57 & E & 12.99 & 556.50 & Peroxide \\
\hline 122 & 1078.40 & E & 12.89 & 548.16 & Peroxide \\
\hline 123 & 1074.31 & E & 12.85 & 544.01 & Peroxide \\
\hline 124 & 1095.57 & E & 13.10 & 565.00 & Peroxide \\
\hline 125 & 1093.46 & E & 13.07 & 563.59 & Peroxide \\
\hline
\end{tabular}


S. Kumar et al.

\section{Continued}

\begin{tabular}{|c|c|c|c|c|c|}
\hline 126 & 1082.48 & $\mathrm{E}$ & 12.94 & 552.33 & Peroxide \\
\hline 127 & 1072.77 & $\mathrm{E}$ & 12.83 & 542.45 & Peroxide \\
\hline 128 & 3435.88 & M & 41.09 & 646.88 & Amide A \\
\hline 129 & 3417.73 & M & 40.88 & 640.07 & Amide A \\
\hline 130 & 3374.80 & $\mathrm{M}$ & 40.36 & 624.09 & Amide A \\
\hline 131 & 3415.63 & $\mathrm{M}$ & 40.85 & 639.28 & Amide A \\
\hline 132 & 3444.05 & M & 41.19 & 649.96 & Amide A \\
\hline 133 & 3435.88 & M & 41.09 & 646.88 & Amide A \\
\hline 134 & 3440.36 & M & 41.15 & 648.57 & Amide A \\
\hline 135 & 3439.96 & M & 41.14 & 648.42 & Amide A \\
\hline 136 & 3415.45 & M & 40.85 & 639.21 & Amide A \\
\hline 137 & 1649.63 & M & 19.73 & 149.11 & Amide I \\
\hline 138 & 1625.89 & M & 19.43 & 144.85 & Amide I \\
\hline 139 & 1641.26 & $\mathrm{M}$ & 19.63 & 147.60 & Amide I \\
\hline 140 & 1638.10 & M & 19.59 & 147.03 & Amide I \\
\hline 141 & 1634.06 & M & 19.54 & 146.31 & Amide I \\
\hline 142 & 1645.52 & M & 19.68 & 148.37 & Amide I \\
\hline 143 & 1638.30 & $\mathrm{M}$ & 19.59 & 147.07 & Amide I \\
\hline 144 & 1546.77 & M & 18.50 & 131.09 & Amide II \\
\hline 145 & 1053.88 & M & 12.60 & 523.53 & Peroxide \\
\hline 146 & 1066.29 & $\mathrm{M}$ & 12.75 & 535.93 & Peroxide \\
\hline 147 & 1066.14 & M & 12.75 & 535.78 & Peroxide \\
\hline 148 & 1070.22 & M & 12.80 & 539.89 & Peroxide \\
\hline 149 & 1055.95 & M & 12.63 & 525.58 & Peroxide \\
\hline 150 & 1123.34 & M & 13.43 & 594.81 & Peroxide \\
\hline 151 & 468.87 & $\mathrm{~N}$ & 5.60 & - & \\
\hline 152 & 460.50 & $\mathrm{~N}$ & 5.50 & - & \\
\hline 153 & 454.45 & $\mathrm{~N}$ & 5.43 & - & \\
\hline 154 & 1585.03 & $\mathrm{~N}$ & 18.95 & & \\
\hline 155 & 1588.10 & $\mathrm{~N}$ & 18.99 & & \\
\hline 156 & 1589.27 & $\mathrm{~N}$ & 19.00 & & \\
\hline 157 & 1364.78 & $\mathrm{~N}$ & 19.55 & & \\
\hline 158 & 616.95 & $\mathrm{~N}$ & 7.37 & & \\
\hline 159 & 488.31 & $\mathrm{~N}$ & 5.84 & & \\
\hline 160 & 613.04 & $\mathrm{~N}$ & 7.33 & & \\
\hline 161 & 526.09 & $\mathrm{~N}$ & 6.29 & & \\
\hline 162 & 469.57 & $\mathrm{~N}$ & 5.61 & & \\
\hline 163 & 608.7 & $\mathrm{~N}$ & 7.28 & & \\
\hline 164 & 526.09 & $\mathrm{~N}$ & 6.29 & & \\
\hline 165 & 437.91 & $\mathrm{~N}$ & 5.66 & & \\
\hline 166 & 612.72 & $\mathrm{~N}$ & 7.32 & & \\
\hline 167 & 513.04 & $\mathrm{~N}$ & 6.13 & & \\
\hline 168 & 617.39 & $\mathrm{~N}$ & 7.38 & & \\
\hline
\end{tabular}




\section{Continued}

\begin{tabular}{|c|c|c|c|c|c|}
\hline 169 & 470.00 & $\mathrm{~N}$ & 5.62 & & \\
\hline 170 & 515.75 & $\mathrm{~N}$ & 6.16 & - & - \\
\hline 171 & 3458.82 & $\mathrm{~N}$ & 41.37 & 655.55 & Amide A \\
\hline 172 & 3472.23 & $\mathrm{~N}$ & 41.53 & 660.64 & Amide A \\
\hline 173 & 3440.64 & $\mathrm{~N}$ & 41.15 & 648.67 & Amide A \\
\hline 174 & 3449.14 & $\mathrm{~N}$ & 41.25 & 655.20 & Amide A \\
\hline 175 & 3453.99 & $\mathrm{~N}$ & 41.30 & 660.9 & Amide A \\
\hline 176 & 3431.43 & $\mathrm{~N}$ & 41.03 & 652.3 & Amide A \\
\hline 177 & 3445.05 & $\mathrm{~N}$ & 41.20 & 657.5 & Amide A \\
\hline 178 & 3418.38 & $\mathrm{~N}$ & 40.88 & 647.36 & Amide A \\
\hline 179 & 3448.82 & $\mathrm{~N}$ & 41.24 & 658.9 & Amide A \\
\hline 180 & 3451.61 & $\mathrm{~N}$ & 41.28 & 660.01 & Amide A \\
\hline 181 & 3446.36 & $\mathrm{~N}$ & 41.21 & 658.0 & Amide A \\
\hline 182 & 3446.12 & $\mathrm{~N}$ & 41.21 & 657.9 & Amide A \\
\hline 183 & 3446.68 & $\mathrm{~N}$ & 41.22 & 658.1 & Amide A \\
\hline 184 & 3250 & $\mathrm{~N}$ & 38.87 & 580.30 & Amide A \\
\hline 185 & 3450.67 & $\mathrm{~N}$ & 41.27 & 654.17 & Amide A \\
\hline 186 & 3450.71 & $\mathrm{~N}$ & 41.27 & 654.19 & Amide A \\
\hline 187 & 3456.84 & $\mathrm{~N}$ & 41.34 & 656.51 & Amide A \\
\hline 188 & 3456.31 & $\mathrm{~N}$ & 41.34 & 656.31 & Amide A \\
\hline 189 & 3473.61 & $\mathrm{~N}$ & 41.54 & 662.90 & Amide A \\
\hline 190 & 3460.40 & $\mathrm{~N}$ & 41.38 & 657.87 & Amide A \\
\hline 191 & 3447.65 & $\mathrm{~N}$ & 41.23 & 653.03 & Amide A \\
\hline 192 & 3457.71 & $\mathrm{~N}$ & 41.35 & 656.84 & Amide A \\
\hline 193 & 3464.16 & $\mathrm{~N}$ & 41.43 & 659.30 & Amide A \\
\hline 194 & 1650.40 & $\mathrm{~N}$ & 19.74 & 149.25 & Amide I \\
\hline 195 & 1632.95 & $\mathrm{~N}$ & 19.53 & 146.11 & Amide I \\
\hline 196 & 1632.57 & $\mathrm{~N}$ & 19.52 & 146.04 & Amide I \\
\hline 197 & 1654.49 & $\mathrm{~N}$ & 19.78 & 149.99 & Amide I \\
\hline 198 & 1631.64 & $\mathrm{~N}$ & 19.51 & 145.87 & Amide I \\
\hline 199 & 1636.72 & $\mathrm{~N}$ & 19.57 & 147.17 & Amide I \\
\hline 200 & 1630.02 & $\mathrm{~N}$ & 19.49 & 145.9 & Amide I \\
\hline 201 & 1637.28 & $\mathrm{~N}$ & 19.58 & 147.2 & Amide I \\
\hline 202 & 1637.75 & $\mathrm{~N}$ & 19.58 & 147.36 & Amide I \\
\hline 203 & 1634.17 & $\mathrm{~N}$ & 19.54 & 113.75 & Amide I \\
\hline 204 & 1639.43 & $\mathrm{~N}$ & 19.6 & 147.66 & Amide I \\
\hline 205 & 1635.36 & $\mathrm{~N}$ & 19.55 & 146.9 & Amide I \\
\hline 206 & 1636.85 & $\mathrm{~N}$ & 19.57 & 147.1 & Amide I \\
\hline 207 & 1630 & $\mathrm{~N}$ & 19.49 & 145.97 & Amide I \\
\hline 208 & 1637.50 & $\mathrm{~N}$ & 19.58 & 147.31 & Amide I \\
\hline 209 & 1637.40 & $\mathrm{~N}$ & 19.58 & 147.32 & Amide I \\
\hline 210 & 1636.23 & $\mathrm{~N}$ & 19.56 & 147.08 & Amide I \\
\hline 211 & 1637.43 & $\mathrm{~N}$ & 19.58 & 147.30 & Amide I \\
\hline
\end{tabular}


S. Kumar et al.

\section{Continued}

\begin{tabular}{|c|c|c|c|c|c|}
\hline 212 & 1634.29 & $\mathrm{~N}$ & 19.54 & 146.73 & Amide I \\
\hline 213 & 1639.13 & $\mathrm{~N}$ & 19.60 & 147.60 & Amide I \\
\hline 214 & 1638.08 & $\mathrm{~N}$ & 19.59 & 147.42 & Amide I \\
\hline 215 & 1637.85 & $\mathrm{~N}$ & 19.58 & 147.37 & Amide I \\
\hline 216 & 1639.70 & $\mathrm{~N}$ & 19.61 & 147.71 & Amide I \\
\hline 217 & 1517.39 & $\mathrm{~N}$ & 18.14 & 126.4 & Amide II \\
\hline 218 & 669.35 & $\mathrm{~N}$ & 8.00 & 24.61 & Amide IV \\
\hline 219 & 541.27 & $\mathrm{~N}$ & 6.47 & 16.09 & Amide IV \\
\hline 220 & 665.22 & $\mathrm{~N}$ & 7.95 & 24.31 & Amide IV \\
\hline 221 & 752.17 & $\mathrm{~N}$ & 8.99 & 31.08 & Amide IV \\
\hline 222 & 704.35 & $\mathrm{~N}$ & 8.42 & 27.25 & Amide IV \\
\hline 223 & 760.87 & $\mathrm{~N}$ & 9.10 & 31.8 & Amide IV \\
\hline 224 & 700.00 & $\mathrm{~N}$ & 8.37 & 26.90 & Amide IV \\
\hline 225 & 667.87 & $\mathrm{~N}$ & 7.98 & 24.50 & Amide VI \\
\hline 226 & 586.04 & $\mathrm{~N}$ & 7.00 & 18.86 & Amide VI \\
\hline 227 & 569.03 & $\mathrm{~N}$ & 6.8 & 17.78 & Amide VI \\
\hline 228 & 580.07 & $\mathrm{~N}$ & 6.93 & 18.48 & Amide VI \\
\hline 229 & 592.36 & $\mathrm{~N}$ & 7.08 & 19.27 & Amide VI \\
\hline 230 & 580.33 & $\mathrm{~N}$ & 6.94 & 18.49 & Amide VI \\
\hline 231 & 584.48 & $\mathrm{~N}$ & 6.99 & 18.76 & Amide VI \\
\hline 232 & 638.00 & $\mathrm{~N}$ & 7.63 & 22.36 & Amide VI \\
\hline 233 & 1383.54 & $\mathrm{~N}$ & 16.54 & 676.71 & $\mathrm{C}=\mathrm{C}$ \\
\hline 234 & 1349.99 & $\mathrm{~N}$ & 16.14 & 644.29 & $\mathrm{C}=\mathrm{C}$ \\
\hline 235 & 1383.56 & $\mathrm{~N}$ & 16.54 & 676.73 & $\mathrm{C}=\mathrm{C}$ \\
\hline 236 & 1350.08 & $\mathrm{~N}$ & 16.14 & 644.37 & $\mathrm{C}=\mathrm{C}$ \\
\hline 237 & 1380.74 & $\mathrm{~N}$ & 16.51 & 673.96 & $\mathrm{C}=\mathrm{C}$ \\
\hline 238 & 1434.7 & $\mathrm{~N}$ & 17.15 & 727.0 & $\mathrm{C}=\mathrm{C}$ \\
\hline 239 & 1391.3 & $\mathrm{~N}$ & 16.63 & 683.6 & $\mathrm{C}=\mathrm{C}$ \\
\hline 240 & 1465.22 & $\mathrm{~N}$ & 17.52 & 758.2 & $\mathrm{C}=\mathrm{C}$ \\
\hline 241 & 1378.26 & $\mathrm{~N}$ & 16.48 & 670.09 & $\mathrm{C}=\mathrm{C}$ \\
\hline 242 & 1295.65 & $\mathrm{~N}$ & 15.49 & 592.9 & $\mathrm{C}=\mathrm{C}$ \\
\hline 243 & 1362.09 & $\mathrm{~N}$ & 15.86 & 621.1 & $\mathrm{C}=\mathrm{C}$ \\
\hline 244 & 1260.87 & $\mathrm{~N}$ & 15.08 & 561.4 & $\mathrm{C}=\mathrm{C}$ \\
\hline 245 & 1390 & $\mathrm{~N}$ & 16.62 & 682.4 & $\mathrm{C}=\mathrm{C}$ \\
\hline 246 & 1385.04 & $\mathrm{~N}$ & 16.56 & 677.55 & $\mathrm{C}=\mathrm{C}$ \\
\hline 247 & 1383.73 & $\mathrm{~N}$ & 16.54 & 676.27 & $\mathrm{C}=\mathrm{C}$ \\
\hline 248 & 1386.30 & $\mathrm{~N}$ & 16.58 & 678.78 & $\mathrm{C}=\mathrm{C}$ \\
\hline 249 & 1384.46 & $\mathrm{~N}$ & 16.55 & 676.98 & $\mathrm{C}=\mathrm{C}$ \\
\hline 250 & 1386.22 & $\mathrm{~N}$ & 16.57 & 678.71 & $\mathrm{C}=\mathrm{C}$ \\
\hline 251 & 1384.07 & $\mathrm{~N}$ & 16.55 & 676.60 & $\mathrm{C}=\mathrm{C}$ \\
\hline 252 & 2806.67 & $\mathrm{~N}$ & 33.57 & 427.01 & $\mathrm{C}-\mathrm{H}$ \\
\hline 253 & 2810.76 & $\mathrm{~N}$ & 33.62 & 428.25 & $\mathrm{C}-\mathrm{H}$ \\
\hline 254 & 2814.84 & $\mathrm{~N}$ & 33.66 & 429.49 & $\mathrm{C}-\mathrm{H}$ \\
\hline
\end{tabular}




\section{Continued}

\begin{tabular}{|c|c|c|c|c|c|}
\hline 255 & 2917.39 & $\mathrm{~N}$ & 34.89 & 462.49 & $\mathrm{C}-\mathrm{H}$ \\
\hline 256 & 2926.03 & $\mathrm{~N}$ & 34.16 & 443.3 & C-H \\
\hline 257 & 2921.74 & $\mathrm{~N}$ & 39.94 & 463.8 & C-H \\
\hline 258 & 2856.52 & $\mathrm{~N}$ & 34.16 & 443.3 & C-H \\
\hline 259 & 1108.66 & $\mathrm{~N}$ & 13.26 & 579.37 & Peroxide \\
\hline 260 & 1098.84 & $\mathrm{~N}$ & 13.14 & 569.15 & Peroxide \\
\hline 261 & 1041.62 & $\mathrm{~N}$ & 12.45 & 511.41 & Peroxide \\
\hline 262 & 1091.53 & $\mathrm{~N}$ & 13.05 & 561.11 & Peroxides \\
\hline 263 & 1077.65 & $\mathrm{~N}$ & 12.55 & 546.93 & Peroxides \\
\hline 264 & 1085.14 & $\mathrm{~N}$ & 12.97 & 556.24 & Peroxides \\
\hline 265 & 1099.06 & $\mathrm{~N}$ & 13.14 & 568.88 & Peroxides \\
\hline 266 & 1095.80 & $\mathrm{~N}$ & 13.10 & 565.51 & Peroxides \\
\hline 267 & 1589.49 & $\mathrm{P}$ & 19.01 & & \\
\hline 268 & 1590.27 & $\mathrm{P}$ & 19.02 & 138.57 & \\
\hline 269 & 1588.73 & $\mathrm{P}$ & 19.50 & & \\
\hline 270 & 1590.94 & $\mathrm{P}$ & 19.02 & & \\
\hline 271 & 3454.13 & $\mathrm{P}$ & 41.31 & 653.39 & Amide A \\
\hline 272 & 3335.04 & $\mathrm{P}$ & 39.89 & 609.83 & Amide A \\
\hline 273 & 3423.50 & $\mathrm{P}$ & 40.94 & 642.23 & Amide A \\
\hline 274 & 3456.06 & $\mathrm{P}$ & 41.33 & 654.88 & Amide A \\
\hline 275 & 3460.56 & $\mathrm{P}$ & 41.39 & 656.21 & Amide A \\
\hline 276 & 3419.44 & $\mathrm{P}$ & 40.90 & 640.70 & Amide A \\
\hline 277 & 3430.08 & $\mathrm{P}$ & 41.02 & 644.70 & Amide A \\
\hline 278 & 3441.35 & $\mathrm{P}$ & 41.16 & 648.94 & Amide A \\
\hline 279 & 3448.15 & $\mathrm{P}$ & 41.24 & 651.51 & Amide A \\
\hline 280 & 3417.78 & $\mathrm{P}$ & 40.88 & 640.09 & Amide A \\
\hline 281 & 3440.14 & $\mathrm{P}$ & 41.14 & 648.49 & Amide A \\
\hline 282 & 3431.04 & $\mathrm{P}$ & 41.03 & 645.06 & Amide A \\
\hline 283 & 3452.74 & $\mathrm{P}$ & 41.29 & 653.25 & Amide A \\
\hline 284 & 3444.05 & $\mathrm{P}$ & 41.19 & 649.96 & Amide A \\
\hline 285 & 1638.79 & $\mathrm{P}$ & 19.60 & 147.16 & Amide I \\
\hline 286 & 1638.14 & $\mathrm{P}$ & 19.59 & 147.04 & Amide I \\
\hline 287 & 1649.30 & $\mathrm{P}$ & 19.72 & 149.05 & Amide I \\
\hline 288 & 1649.41 & $\mathrm{P}$ & 19.72 & 149.07 & Amide I \\
\hline 289 & 1649.27 & $\mathrm{P}$ & 19.72 & 149.05 & Amide I \\
\hline 290 & 1649.58 & $\mathrm{P}$ & 19.73 & 149.10 & Amide I \\
\hline 291 & 1649.72 & $\mathrm{P}$ & 19.73 & 149.13 & Amide I \\
\hline 292 & 1654.49 & $\mathrm{P}$ & 19.78 & 149.99 & Amide I \\
\hline 293 & 1649.83 & $\mathrm{P}$ & 19.73 & 149.15 & Amide I \\
\hline 294 & 1634.05 & $\mathrm{P}$ & 19.54 & 146.30 & Amide I \\
\hline 295 & 1654.49 & $\mathrm{P}$ & 19.78 & 149.99 & Amide I \\
\hline 296 & 1632.18 & $\mathrm{P}$ & 19.52 & 145.97 & Amide I \\
\hline 297 & 1642.23 & $\mathrm{P}$ & 19.64 & 147.78 & Amide I \\
\hline
\end{tabular}


S. Kumar et al.

\section{Continued}

\begin{tabular}{|c|c|c|c|c|c|}
\hline 298 & 1649.21 & $\mathrm{P}$ & 19.72 & 149.04 & Amide I \\
\hline 299 & 1647.73 & $\mathrm{P}$ & 19.70 & 148.77 & Amide I \\
\hline 300 & 1649.57 & $\mathrm{P}$ & 19.73 & 149.10 & Amide I \\
\hline 301 & 1649.62 & $\mathrm{P}$ & 19.73 & 149.11 & Amide II \\
\hline 302 & 1638.14 & $\mathrm{P}$ & 19.59 & 147.04 & Amide II \\
\hline 303 & 767.76 & $\mathrm{P}$ & 9.18 & 32.30 & Amide V \\
\hline 304 & 771.97 & $\mathrm{P}$ & 9.23 & 32.65 & Amide V \\
\hline 305 & 1348.06 & $\mathrm{P}$ & 16.10 & 642.43 & $\mathrm{C}=\mathrm{C}$ \\
\hline 306 & 1381.81 & $\mathrm{P}$ & 16.52 & 675.02 & $\mathrm{C}=\mathrm{C}$ \\
\hline 307 & 1383.18 & $\mathrm{P}$ & 16.54 & 676.36 & $\mathrm{C}=\mathrm{C}$ \\
\hline 308 & 1350.34 & $\mathrm{P}$ & 16.15 & 644.62 & $\mathrm{C}=\mathrm{C}$ \\
\hline 309 & 1383.51 & $\mathrm{P}$ & 16.54 & 676.65 & $\mathrm{C}=\mathrm{C}$ \\
\hline 310 & 1350.37 & $\mathrm{P}$ & 16.15 & 644.65 & $\mathrm{C}=\mathrm{C}$ \\
\hline 311 & 1383.54 & $\mathrm{P}$ & 16.54 & 677.69 & $\mathrm{C}=\mathrm{C}$ \\
\hline 312 & 1350.13 & $\mathrm{P}$ & 16.14 & 644.24 & $\mathrm{C}=\mathrm{C}$ \\
\hline 313 & 1383.55 & $\mathrm{P}$ & 16.54 & 678.68 & $\mathrm{C}=\mathrm{C}$ \\
\hline 314 & 1350.42 & $\mathrm{P}$ & 16.15 & 644.76 & $\mathrm{C}=\mathrm{C}$ \\
\hline 315 & 1372.53 & $\mathrm{P}$ & 16.41 & 645.98 & $\mathrm{C}=\mathrm{C}$ \\
\hline 316 & 2815.89 & $\mathrm{P}$ & 33.68 & 429.82 & $\mathrm{C}-\mathrm{H}$ \\
\hline 317 & 2716.78 & $\mathrm{P}$ & 32.49 & 400.09 & $\mathrm{C}-\mathrm{H}$ \\
\hline 318 & 2815.84 & $\mathrm{P}$ & 33.68 & 429.80 & $\mathrm{C}-\mathrm{H}$ \\
\hline 319 & 2729.17 & $\mathrm{P}$ & 32.64 & 403.75 & C-H \\
\hline 320 & 2810.76 & $\mathrm{P}$ & 33.62 & 428.25 & $\mathrm{C}-\mathrm{H}$ \\
\hline 321 & 2815.77 & $\mathrm{P}$ & 33.68 & 429.78 & C-H \\
\hline 322 & 2729.04 & $\mathrm{P}$ & 32.60 & 403.71 & C-H \\
\hline 323 & 2913.05 & $\mathrm{P}$ & 34.86 & 459.90 & $\mathrm{C}-\mathrm{H}$ \\
\hline 324 & 1069.37 & $\mathrm{P}$ & 12.79 & 539.03 & Peroxide \\
\hline 325 & 1053.88 & $\mathrm{P}$ & 12.60 & 523.53 & Peroxide \\
\hline 326 & 1071.11 & $\mathrm{P}$ & 12.81 & 541.39 & Peroxide \\
\hline 327 & 1102.91 & $\mathrm{P}$ & 13.19 & 573.37 & Peroxide \\
\hline 328 & 1078.40 & $\mathrm{P}$ & 12.89 & 548.17 & Peroxide \\
\hline 329 & 1102.04 & $\mathrm{P}$ & 13.18 & 572.46 & Peroxide \\
\hline 330 & 1068.64 & $\mathrm{P}$ & 12.78 & 538.28 & Peroxide \\
\hline 331 & 1081.41 & $\mathrm{P}$ & 12.93 & 551.23 & Peroxide \\
\hline 332 & 1072.29 & $\mathrm{P}$ & 12.82 & 541.98 & Peroxide \\
\hline 333 & 1119.18 & $\mathrm{P}$ & 13.38 & 590.41 & Peroxide \\
\hline 334 & 1076.86 & $\mathrm{P}$ & 12.88 & 546.61 & Peroxide \\
\hline 335 & 1098.83 & $\mathrm{P}$ & 13.14 & 569.14 & Peroxide \\
\hline 336 & 1074.71 & $\mathrm{P}$ & 12.85 & 544.43 & Peroxide \\
\hline 337 & 1069.80 & $\mathrm{P}$ & 12.79 & 539.46 & Peroxide \\
\hline
\end{tabular}


Table A2. Main features of infrared band present in protein structure.

\begin{tabular}{cccc}
\hline S. No. & Frequency $\left.\mathbf{( c m}^{-1}\right)$ & Assignment & Description \\
\hline 1 & 3300 & Amide A & N-H stretching \\
2 & 3100 & Amide B & N-H stretching \\
3 & $1600-1690$ & Amide I & C=0 stretching \\
4 & $1480-1575$ & Amide II & CN stretching \\
5 & $1229-1301$ & Amide III & N-H bending \\
6 & $625-767$ & Amide IV & N-H bending \\
7 & $640-800$ & Amide V & OCN bending \\
8 & $537-606$ & Amide VI & Out of plane bending \\
9 & 200 & Amide VII & C=O bending skeletal torsion \\
\hline
\end{tabular}

Table A3. Main features of infrared band present in protein structure of the present work.

\begin{tabular}{|c|c|c|c|c|}
\hline S.N. & Disease sample & Frequency $\left(\mathrm{cm}^{-1}\right)$ & Assignment & Description \\
\hline 1 & Epilepsy & $3380.04 \mathrm{~cm}^{-1}-3480.74 \mathrm{~cm}^{-1}$ & Amide A & N-H stretching \\
\hline 2 & Migraine & $3415.45 \mathrm{~cm}^{-1}-344.36 \mathrm{~cm}^{-1}$ & Amide A & N-H stretching \\
\hline 3 & Paralysis & $3417.78 \mathrm{~cm}^{-1}-3460.56 \mathrm{~cm}^{-1}$ & Amide A & $\mathrm{N}-\mathrm{H}$ stretching \\
\hline 4 & Alzheimer & $3433.69 \mathrm{~cm}^{-1}-3453.93 \mathrm{~cm}^{-1}$ & Amide A & N-H stretching \\
\hline 5 & Duchenne muscular dystrophy & $3440.13 \mathrm{~cm}^{-1}-3460.75 \mathrm{~cm}^{-1}$ & Amide A & $\mathrm{N}-\mathrm{H}$ stretching \\
\hline 6 & Normal & $3250.00 \mathrm{~cm}^{-1}-3473.61 \mathrm{~cm}^{-1}$ & Amide A & N-H stretching \\
\hline 7 & Paralysis & $2810.76 \mathrm{~cm}^{-1}-2815.89 \mathrm{~cm}^{-1}$ & C-H & Hydrocarbon \\
\hline 8 & Alzheimer & $2852.17 \mathrm{~cm}^{-1}-2921.74 \mathrm{~cm}^{-1}$ & $\mathrm{C}-\mathrm{H}$ & Hydrocarbon \\
\hline 9 & Normal & $2806.67 \mathrm{~cm}^{-1}-2926.03 \mathrm{~cm}^{-1}$ & $\mathrm{C}-\mathrm{H}$ & Hydrocarbon \\
\hline 10 & Epilepsy & $1649.11 \mathrm{~cm}^{-1}-1651.99 \mathrm{~cm}^{-1}$ & Amide I & $\mathrm{N}-\mathrm{H}$ stretching \\
\hline 11 & Migraine & $1625.89 \mathrm{~cm}^{-1}-1649.63 \mathrm{~cm}^{-1}$ & Amide I & N-H stretching \\
\hline 12 & Paralysis & $1632.18 \mathrm{~cm}^{-1}-1649.72 \mathrm{~cm}^{-1}$ & Amide I & N-H stretching \\
\hline 13 & Alzheimer & $1631.71 \mathrm{~cm}^{-1}-1638.44 \mathrm{~cm}^{-1}$ & Amide I & N-H stretching \\
\hline 14 & Normal & $1630.00 \mathrm{~cm}^{-1}-1654.49 \mathrm{~cm}^{-1}$ & Amide I & N-H stretching \\
\hline 15 & Duchenne muscular dystrophy & $1633.44 \mathrm{~cm}^{-1}-1642.76 \mathrm{~cm}^{-1}$ & Amide I & $\mathrm{N}-\mathrm{H}$ stretching \\
\hline 16 & Paralysis & $1348.06 \mathrm{~cm}^{-1}-1383.55 \mathrm{~cm}^{-1}$ & $\mathrm{C}=\mathrm{C}$ & Carbide \\
\hline 17 & Alzheimer & $1391.30 \mathrm{~cm}^{-1}-1482.61 \mathrm{~cm}^{-1}$ & $\mathrm{C}=\mathrm{C}$ & Carbide \\
\hline 18 & Duchenne muscular dystrophy & $1380.17 \mathrm{~cm}^{-1}-1384.30 \mathrm{~cm}^{-1}$ & $\mathrm{C}=\mathrm{C}$ & Carbide \\
\hline 19 & Normal & $1260.87 \mathrm{~cm}^{-1}-1465.22 \mathrm{~cm}^{-1}$ & $\mathrm{C}=\mathrm{C}$ & Carbide \\
\hline 20 & Duchenne muscular dystrophy & $1005.04 \mathrm{~cm}^{-1}-1090.36 \mathrm{~cm}^{-1}$ & $\mathrm{O}-\mathrm{O}$ & Peroxides \\
\hline 21 & Normal & $1041.62 \mathrm{~cm}^{-1}-1108.66 \mathrm{~cm}^{-1}$ & $\mathrm{O}-\mathrm{O}$ & Peroxides \\
\hline 22 & Epilepsy & $1072.77 \mathrm{~cm}^{-1}-1095.57 \mathrm{~cm}^{-1}$ & $\mathrm{O}-\mathrm{O}$ & Peroxides \\
\hline 23 & Migraine & $1053.88 \mathrm{~cm}^{-1}-1123.34 \mathrm{~cm}^{-1}$ & $\mathrm{O}-\mathrm{O}$ & Peroxides \\
\hline 24 & Paralysis & $1053.88 \mathrm{~cm}^{-1}-1119.18 \mathrm{~cm}^{-1}$ & $\mathrm{O}-\mathrm{O}$ & Peroxides \\
\hline 25 & Alzheimer & $1108.70 \mathrm{~cm}^{-1}-1108.70 \mathrm{~cm}^{-1}$ & $\mathrm{O}-\mathrm{O}$ & Peroxides \\
\hline 26 & Paralysis & $767.76 \mathrm{~cm}^{-1}-771.97 \mathrm{~cm}^{-1}$ & AmideIV & $\mathrm{N}-\mathrm{H}$ stretching \\
\hline 27 & Alzheimer & $700.00 \mathrm{~cm}^{-1}-752.17 \mathrm{~cm}^{-1}$ & AmideIV & $\mathrm{N}-\mathrm{H}$ stretching \\
\hline 28 & Duchenne muscular dystrophy & $660.17 \mathrm{~cm}^{-1}-666.71 \mathrm{~cm}^{-1}$ & AmideIV & N-H stretching \\
\hline 29 & Normal & $541.27 \mathrm{~cm}^{-1}-752.17 \mathrm{~cm}^{-1}$ & AmideIV & N-H stretching \\
\hline 30 & Alzheimer & $717.39 \mathrm{~cm}^{-1}-717.39 \mathrm{~cm}^{-1}$ & AmideV & N-H stretching \\
\hline
\end{tabular}


Table A4. Amide I band frequencies and assignments to the secondary structure of proteins.

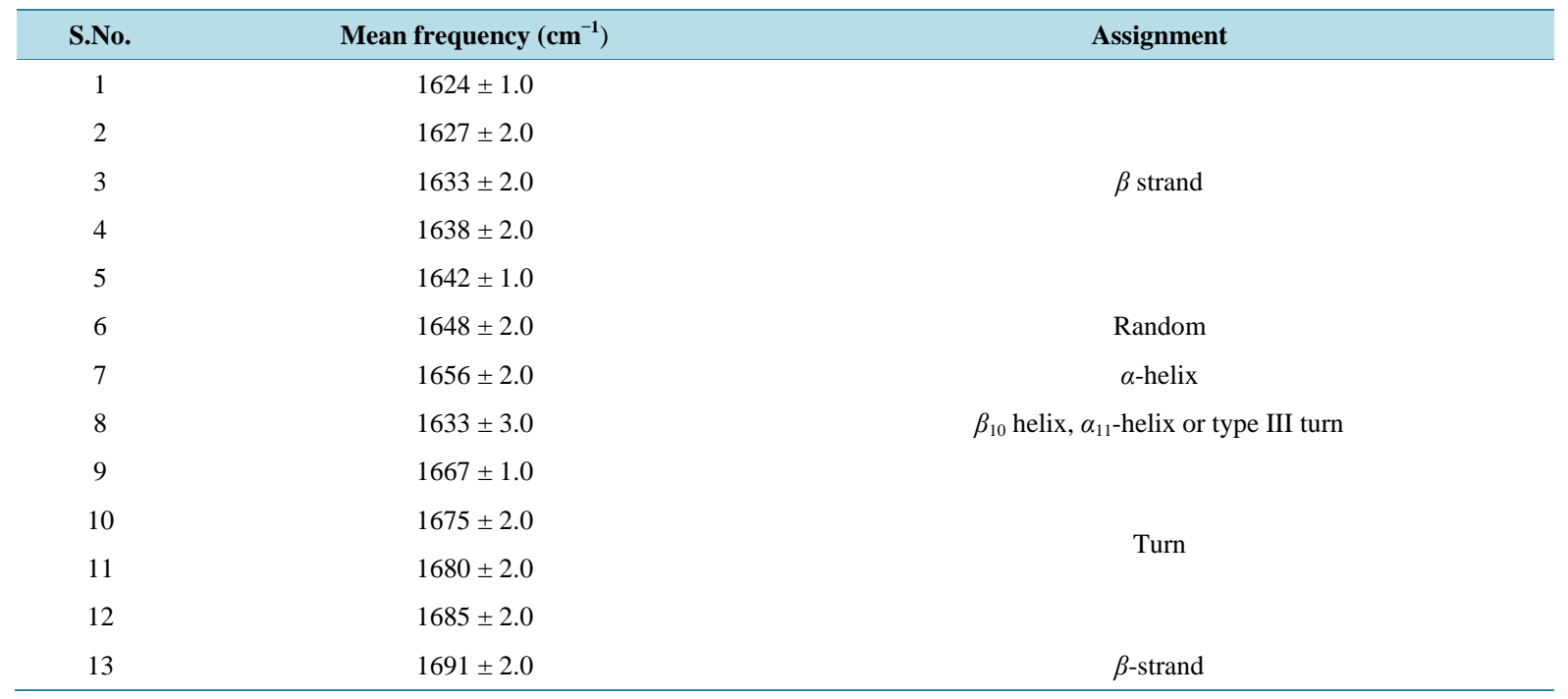

Table A5. Characteristic side-chain frequencies.

\begin{tabular}{|c|c|c|}
\hline S.No. & Residuce & Infrared frequency $\left(\mathrm{cm}^{-1}\right)$ \\
\hline 1 & Alamine & $\sim 1465$ \\
\hline 2 & Valanine & $\sim 1450$ \\
\hline 3 & Leucine & $\sim 1375$ \\
\hline 4 & Isoleucine & - \\
\hline 5 & Serine & $1350 \mathrm{~cm}^{-1}-1250 \mathrm{~cm}^{-1}$ \\
\hline 6 & Thronine & - \\
\hline 7 & Asparagine & $1720 \mathrm{~cm}^{-1}$ \\
\hline 8 & Glutamine & 1560 \\
\hline 9 & Asn & $\sim 1650$ \\
\hline 10 & Glycine & 1615 \\
\hline 11 & lysine & 1645-1610, 1550-1485, 1160, 1100 \\
\hline 12 & Histidine & - \\
\hline 13 & Phenylalanine & $1602, \sim 1450,760,700$ \\
\hline 14 & Tyrosine & $\sim 1600$ \\
\hline 15 & Tryptophn & - \\
\hline
\end{tabular}

